\title{
ISSN 2500-3690
}
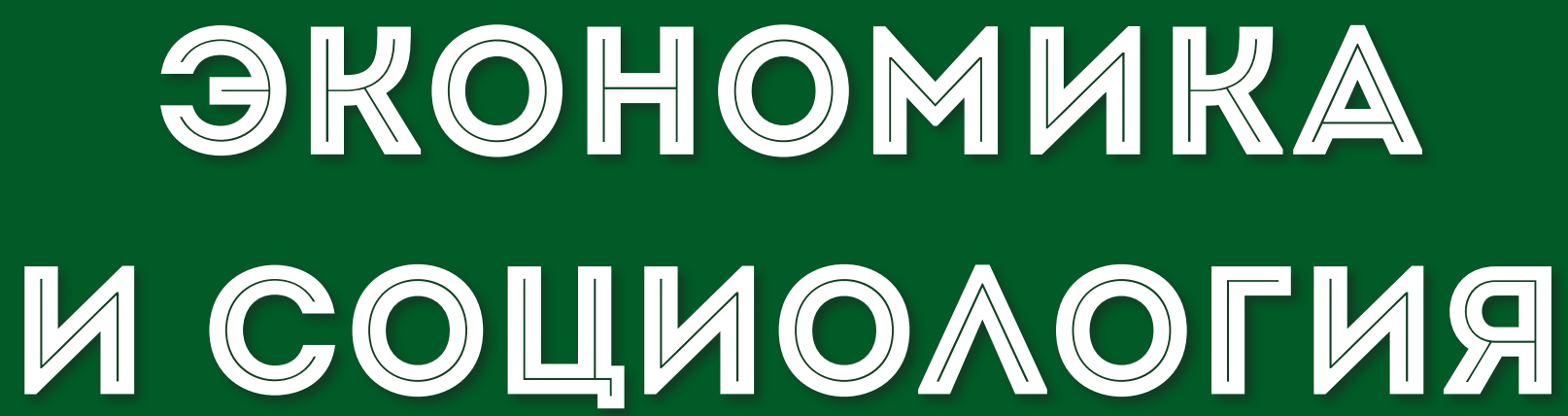

№2 (38)

2018 


\section{Редакционный совет:}

С.А. Барков - доктор социологических наук, профессор, заведующий кафедрой социологии организаций и менеджмента социологического факультета МГУ им. М.В. Ломоносова

А.Г. Зельднер - доктор экономических наук, профессор Института экономики Российской академии наук В.И. Зубков - доктор социологических наук, профессор Московского авиационного института (национальный исследовательский университет)

Н.П. Кетова - доктор экономических наук, профессор, заслуженный деятель науки РФ, заведующий кафедрой “Маркетинг и коммуникации в бизнесе” Южного федерального университета

О.Ю. Мамедов - доктор экономических наук, профессор Южного федерального университета

O.E. Рязанова - доктор экономических наук, профессор кафедры экономической теории Московского государственного института международных отношений (университета) Министерства иностранных дел Российской Федерации (МГИМО), главный редактор журнала «Экономика и социология»

С.Н. Сильвестров - доктор экономических наук, профессор, руководитель департамента мировой экономики и международных финансовых отношений Финансового университета при Правительстве РФ

\section{Главный редактор}

O.Е. Рязанова - доктор экономических наук, професcop

\section{Компьютерная правка и верстка А.С. Голубев}

\section{Редакционная коллегия:}

O.Е. Рязанова - доктор экономических наук, профессор кафедры экономической теории Московского государственного института международных отношений (университета) Министерства иностранных дел Российской Федерации (МГИМО), главный редактор журнала «Экономика и социология»

H.E. Фомина - доктор экономических наук, заместитель главного редактора журнала «Экономика и социология»

H.В. Авдошина - кандидат социологических наук, доцент, директор НИИ социальных технологий Самарского национального исследовательского университета им. академика С.П. Королева

С.А. Барков - доктор социологических наук, профессор, заведующий кафедрой социологии организаций и менеджмента социологического факультета МГУ им. М.В. Ломоносова

В.И. Зубков - доктор социологических наук, профессор Московского авиационного института (национальный исследовательский университет)

Н.П. Кетова - доктор экономических наук, профессор, заслуженный деятель науки РФ, заведующий кафедрой “Маркетинг и коммуникации в бизнесе” Южного федерального университета

Н.Ф. Тагирова - доктор исторических наук, профессор, заведующий кафедрой «Институциональная экономика и экономическая история» Самарского государственного экономического университета

Р.И. Хансевяров - доктор экономических наук, профессор Самарского государственного экономического университета

B.A. Савинова - доктор экономических наук, профессор кафедры финансов и кредита Самарского государственного экономического университета

Дата выхода издания 30.06.2018 г.

Формат 60х84/8

Усл. печ. л. 7.32

Тираж 500 экз.

Отпечатано в типографии 000 «24 Принт»
Свидетельство о регистрации средства массовой информации: ПИ № ФС77-64819 от 2 февраля 2016 г.

Подписной индекс 80674 (Агентство «Роспечать») 

СОДЕРЖАНИЕ

социология

\section{ТЕОРИЯ, МЕТОДОЛОГИЯ И ИСТОРИЯ СОЦИОЛОГИИ}

Ходыкин А.В. Теоретическое осмысление профориентации школьников в контексте социологического подхода

\section{СОЦИАЛЬНАЯ СТРУКТУРА, СОЦИАЛЬНЫЕ ИНСТИТУТЫ И ПРОЦЕССЫ}

Хаджалова Х.М., Абдулманапов С.Г. Протестные настроения в Республике Дагестан (по данным социологического опроса)

\section{ЭКОНОМИКА. ЭКОНОМИЧЕСКИЕ НАУКИ}

\section{ЭКОНОМИЧЕСКАЯ ТЕОРИЯ}

Лебедев К.Н. Незаслуженное обвинение в экономическом детерминизме, и почему Ф. Энгельс не раскрыл метод К. Маркса

Будович Ю.И. Обладал ли К. Маркс экономическим взглядом на хозяйственную деятельность?

\section{ЭКОНОМИКА И УПРАВЛЕНИЕ НАРОДНЫМ ХОЗЯЙСТВОМ}

Зельднер А.Г. К модели развития дальневосточных территорий: реальность и перспективы 33

Захарченко И.С. Сущность и инструменты антикризисного менеджмента 38

\section{ФИНАНСЫ, ДЕНЕЖНОЕ ОБРАЩЕНИЕ И КРЕДИТ}

Ливенский В.М. Функциональное значение фондового рынка для развития экономики

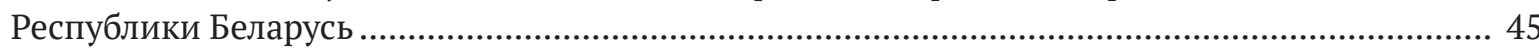

Валиева Е.Н., Курнакина Н.В. Финансовый механизм медицинских организаций в РФ .... 51 

социология

\section{ТЕОРИЯ, МЕТОДОЛОГИЯ И ИСТОРИЯ СОЦИОЛОГИИ}





\title{
ТЕОРЕТИЧЕСКОЕ ОСМЫСЛЕНИЕ ПРОФОРИЕНТАЦИИ ШКОЛЬНИКОВ В КОНТЕКСТЕ СОЦИОЛОГИЧЕСКОГО ПОДХОДА
}

\author{
(c) 2018 Ходыкин Александр Владимирович \\ НИИ социальных технологий \\ Самарский национальный исследовательский университет имени академика С.П. Королева \\ 443086, Россия, г. Самара, ул. Московское шоссе, д. 34 \\ E-mail: avhod@yandex.ru
}

В статье выделены и подробно охарактеризованы следующие направления теоретического осмысления профориентации школьников: профориентация как социокультурный процесс, как социальный институт, как социальная деятельность и как система социальных отношений.

Ключевые слова: профориентация, школьники, процесс, институт, деятельность, социологический подход, подходы к профориентации, исследования профориентации.

Профориентация школьников представляет собой сложный комплексный социальный феномен, имеющий междисциплинарный характер и включающий в себя элементы педагогики, психологии, философии, экономики, социологии, медицины и физиологии. Методология перечисленных наук становится базой для формирования соответствующих научных подходов к профориентации школьников [1].

Большое значение профориентации школьников для качественной подготовки трудовых резервов общества, воспроизводства его социально-профессиональной структуры и его развития в целом обусловливает актуальность исследований профориентации школьников с социологических позиций. Подобные исследования проводились ещё такими классиками социологии, как Карл Маркс и Толкотт Парсонс [2], [3]. В настоящее время социологическая наука содержит широкий круг исследований, создающих базу для формирования социологического подхода к исследованию профориентации школьников. Вместе с тем, проводимые в рамках социологической науки исследования профориентации школьников нуждаются в теоретической систематизации.

Фокус внимания теоретических исследований профориентации школьников в контексте социологического подхода, на наш взгляд, следует сосредоточить на выявлении новых перспективных направлений исследования профориентации школьников, а также на теоретическом осмыслении и систематизации комплекса эмпирических исследований профориентации школьников в контексте социальной системы и социальных отношений, характер- ных для данного общества. Под теоретическим осмыслением в современной науке понимается вид познавательных процессов, которые основаны на вербально-логической функции и характерны для теоретического общества, а также имеют соответствующую им динамическую смысловую систему [4]. Анализ научных источников и результатов эмпирических исследований позволяет сделать вывод о том, что, с точки зрения социологического подхода, профориентация школьников может быть теоретически осмыслена по следующим ключевым направлениям: профориентация как социокультурный процесс, как социальный институт, как социальная деятельность и как система социальных отношений. Более подробно охарактеризуем каждое из перечисленных направлений.

Профориентация как социокультурный процесс представляет собой осуществляющийся в контексте социокультурных условий данного общества процесс профессионального самоопределения школьника путём выбора им рода профессиональной деятельности, стратегии профессионального развития и желаемого профессионального и социального статуса. Социокультурный характер процесса профориентации проявляется формированием трансформирующегося комплекса социокультурных факторов, отражающих социокультурные условия профориентации школьников. К таким факторам на макросоциальном уровне следует отнести экономические, политические, социальные и культурные условия общества, а также текущую и прогнозируемую ситуацию на рынке труда и его особенности, моду и представления о престижности профессий, сложившиеся в данном обще- 
стве. На микросоциальном уровне на процесс профориентации школьника оказывают влияние непосредственные субъекты его профориентации, такие как школа или семья, а также социально-экономические условия жизни, социальный и профессиональный статус родителей, уровень дохода семьи, семейные ценности и традиции и т.д. Следует отметить, что исследования социокультурного процесса профориентации школьников необходимо проводить с учётом анализа взаимодействия социальных явлений, характерных для профессионального самоопределения школьников, с социальными явлениями, характерными для трудовой сферы общества, в котором осуществляется процесс профессионального самоопределения.

Профориентация школьников как социальный институт в широком смысле - это исторически сложившаяся, экономически, политически, социально и культурно обусловленная, изменяющаяся под влиянием трансформации общества форма организации взаимодействия акторов профориентации школьников и социальной системы, в рамках которой она проводится, с целью эффективного воспроизводства профессиональной структуры общества, а также создания оптимальных условий для успешной профессиональной самореализации личности. В узком смысле - это форма организации деятельности по профориентации школьников, характерная для данного общества. Поскольку профориентация является одним из направлений социализации, институт профориентации школьников включён в сеть институтов их социализации, к которым относятся: школа, семья, система дополнительного образования, средства массовой коммуникации, общественные организации и т.д. Посредством института профориентации осуществляется организация и реализация государственной политики в области профориентационной работы со школьниками.

Профориентация школьников как социальная деятельность - это комплексная, научно обоснованная деятельность акторов профориентации, направленная на оказание школьнику содействия в выборе профессии, компромиссно удовлетворяющей его собственным социально-профессиональным интересам, интересам общества, государства и рынка труда. Изучение профориентации как социальной деятельности заключается в исследовании непосредственной работы акторов профориентационной деятель- ности по её организации и осуществлению для достижения её целей и задач. На микросоциальном уровне исследуется профориентационная деятельность непосредственных акторов профориентации: школьных психологов, специалистов-профориентаторов центров занятости и карьеры, специалистов центров профориентации и т.д. и социальные факторы, оказывающие на неё влияние. На макросоциальном уровне предметом изучения является деятельность должностных лиц и возглавляемых ими учреждений по созданию, организации и обеспечению функционирования общегосударственной системы профориентации. Исследованию организации и осуществления профориентационной деятельности посвящён комплекс российских научных исследований.

В контексте социологического подхода профориентация школьников исследуется и как система социальных отношений, возникающих в процессе профориентации между школьником и другими социальными акторами, осуществляющими его профориентацию или напрямую влияющими на процесс его профессионального самоопределения. Социальный процесс профориентации школьников протекает в контексте сети пронизывающих его социальных отношений, исследование которых даёт ключ к пониманию многих социальных аспектов профориентации. В контексте исследования системы социальных отношений, инкорпорированных в процесс профориентации, может быть изучено влияние мнения родителей на профессиональное самоопределение школьника в контексте системы отношений между школьником и его родителями и возможные конфликты, возникающие на основании разногласий по поводу профессионального выбора школьника; влияние личности профориентатора или иного лица, выполняющего его функции, а также влияние референтной группы, мнения авторитетного для школьника человека и мнений социального окружения школьника на результат его профориентации. Следует отметить, что на сегодняшний день в российской науке имеется выраженная недостаточность социологических исследований системы социальных отношений в контексте профориентации школьников, однако некоторые работы всё же можно выделить. Влияние отношений в семье, отношений с родителями и с социальным окружением на профессиональное самоопределение школьника обосновано в ра- 
боте В.А. Цвыка, исследующего профессиональное самоопределение в контексте профессионализации [5]. Количественные характеристики профессиональной преемственности поколений представлены в результатах социологического исследования социальной стратификации российского общества, проводившегося Институтом социологии РАН [6].

Подводя итоги работы, мы можем сделать вывод о наличии в рамках социологического подхода ряда ключевых направлений, систематизирующих теоретические представления относительно профориентации школьников. Анализ социокультурных условий общества, формирующих специфику протекающего в данном обществе процесса профориентации, даёт ключ к пониманию профориентации школьников как социокультурного процесса. Значение профориентации школьников как социального института раскрывается исследованиями формы организации профориентационной деятельности, проводимой сетью социальных институтов, осуществляющих социализацию школьников. Если институциональное направление профо- риентации школьников характеризует форму её организации, то деятельностное направление наполняет эту форму содержанием профориентационной деятельности социальных акторов. Изучение профориентации школьников как социальной деятельности даёт возможность выявить сущность, определить характеристики и обозначить направления работы социальных акторов по организации и проведению профориентации школьников. Анализируя профориентацию школьников как систему социальных отношений, инкорпорированных в процесс профориентации, мы можем охарактеризовать влияние особенностей сети социальных отношений и социальных ориентиров на профессиональное самоопределение школьника.

Таким образом, исследования профориентации школьников по охарактеризованным в работе направлениям формируют комплексное понимание профориентации школьников как социального феномена, что можно считать теоретическим основанием социологического подхода к профориентации школьников.

\section{Библиографический список}

1. Дементьев И.В. Профессиональная ориентация: анализ научных подходов // Кіраванне у адукацыі. 2008. № 11. С. 56-62.

2. Маркс К. Размышления юноши при выборе профессии // Маркс К., Энгельс Ф. Сочинения. 2-е изд. Москва. 1975. T. 40 .

3. Парсонс Т. Профессии и социальная структура // Социология. 2015. Вып. 4. С. 153-170.

4. Пономарев И.В. Дискуссионные вопросы кросс-культурных исследований влияния грамотности на когнитивное развитие и концепция симпрактического общества // Культурно-историческая психология, 2007. № 4. C. 59-67.

5. Ц Цвык В.А. Профессионализация как социальный процесс // Вестник РУДН, серия «Социология», $2003 .-$ № 4. C. 258-269.

6. Социальная стратификация современного российского общества / Под ред. З.Т. Голенковой. Москва. 2003. 

социология

\section{СОЦИАЛЬНАЯ СТРУКТУРА, СОЦИАЛЬНЫЕ ИНСТИТУТЫ И ПРОЦЕССЫ}





\title{
ПРОТЕСТНЫЕ НАСТРОЕНИЯ В РЕСПУБЛИКЕ ДАГЕСТАН (ПО ДАННЫМ СОЦИОЛОГИЧЕСКОГО ОПРОСА)
}

\author{
(c) 2018 Хаджалова Хадижат Магомедовна \\ доктор экономических наук, доцент, ведущий научный сотрудник \\ Институт социально-экономических исследований Дагестанского научного центра РАН \\ профессор кафедры «Управление проектами и программами» \\ Дагестанский государственный университет народного хозяйства \\ 367030, Россия, Республика Дагестан, г. Махачкала, улица Ярагского, д. 75 \\ E-mail: chaha@mail.ru \\ (c) 2018 Абдулманапов Салихбек Габибуллаевич \\ доктор экономических наук, профессор \\ директор НИИ «Управления, экономики, политики и социологии» \\ Дагестанский государственный университет народного хозяйства \\ 367030, Россия, Республика Дагестан, г. Махачкала, улица Ярагского, д. 75 \\ E-mail: salih@mail.ru
}

Статья посвящена выявлению протестных настроений жителей республики в 2017 г. Проведено сопоставление с аналогичным авторским исследованием 2007 г. Выявлены причины роста напряженности в обществе, факторы протестной активности населения, а также закономерности, определяющие их интенсивность и характер проявления. Результаты оценки социальной напряженности в Республике Дагестан и уровня протестной активности свидетельствуют об обеспокоенности и недовольстве людей в целом социально-экономической ситуацией в регионе.

Ключевые слова: протестная активность, протестные настроения, протестный потенциал, Республика Дагестан.

Введение. В настоящее время современное российское общество в своем развитии переживает период кризиса, который активно проявляется в росте социальной напряженности в различных сферах общественной жизни. Социальный протест является определенным критерием социальной напряженности. Исследование сущности социального протеста и форм его проявления является одним из наиболее важных аспектов изучения и прогнозирования развития общества и предупреждения социальных конфликтов. Возникновение социального протеста как формы выражения неудовлетворенности населения уровнем и качеством жизни является угрозой функционирования экономической системы, способной породить масштабный экономический кризис.

Основная часть. С целью исследования протестных настроений авторами в 2017 г. проведен опрос «Потенциал протеста». Опрос проводился среди 200 респондентов жителей Республики Дагестан, которые отвечали на вопросы: есть ли потенциал протеста в регионе, с чем он связан и к каким последствиям могут привести те или иные действия протестующих. Подобное исследование было проведено в 2007 г., его и будем использовать как базовый период (выборка 500 человек) [2].

В опросе приняли участие как сельское, так и городское население республики. Причем, городское (в 2007 г. $-66,8 \%$ и в 2017 г. $-66,2 \%$ ) в три раза превышало сельское вследствие того, что жители сел очень тяжело «идут на контакт». Основная часть опрощенных - женщины (в 2007 г. - 59,6\%, в 2017 г.- 56,3\%). Основной возраст респондентов приходился на 18-30 лет (свыше 40\%) и 31-55 лет (около 40\%). Большинство участников опроса - это люди с высшим (в среднем 46\%) и со средне специальным (около $20 \%)$ образованием.

Оценивая современную ситуацию в соответствии с вышеотмеченными характеристиками, следует отметить, что большинство жителей Дагестана испытывают неудовлетворенность своим положением в обществе, материальными условиями жизни, не доверяют общественным структурам и политическим институтам. 
Рассматривая политическую ситуацию 2017 г. в Республике Дагестан, свыше 50\% опрошенных расценивают ее как напряженную, а $26,4 \%$ - критическую и даже взрывоопасную (см. рисунок 1), притом, что в 2007 г. эта цифра составляла $8,4 \%$.

Также в 2017 г. вдвое сократилась доля лиц, расценивающих политическую ситуацию в республике как «спокойная» (в 2017 г.- 14,0\%, а в 2007 г.- 25,2\%) При этом жители региона не надеются на какое-либо улучшение ситуации. Если в 2007 г. 57,4\% населения надеялось на какое-либо улучшение политической обстановки в республике, то в 2017 г. доля сократилась до $16,4 \%$, и обратная ситуация наблюдается с теми, кто надеялся на какое-либо ухудшение политической ситуации. Их доля увеличилась с 17,8\% в 2007 г. до 56,1\% в 2017 г. Это, как правило, является следствием недоверия деятельности Главы Республики Дагестан. Если в 2007 г.- 21,2\% «полностью и в основном не одобряли» деятельность Главы Республики Дагестан», то к 2017 г. их доля удвоилась $(43,7 \%)$. Лишь $1 / 5$ часть респондентов постоянна в своем числе и «полностью и в основном» одобряют его деятельность.

По мнению респондентов руководителей республики должно заботить, прежде всего, материальное положение населения (32,2\% опрошенных в 2017 г.) порядок в республике $(32,1 \%)$ и экономическое положение в республике (26,1\%). Но между тем большая часть населения (48,0\% в 2007 г. и 50,4\% в 2017 г.) не надеялись на улучшение благосостояния своей семьи ни через полгода, ни через год (41,2\% в 2017 г). В 2007 г. $27,5 \%$ населения считает, что «богатые становят- ся богаче, а бедные беднее», а в 2017 г. их число увеличилось еще на 7,7\%. Четверть населения (22,3\% в 2007 г. и 29,9\% в 2017 г.) считают, что «людям у власти нет дела до меня».

Налицо полное недоверие к различным общественным структурам и политическим институтам. Наибольшее доверие отдано мечети (25,9\% респондентов в 2007 г. и 35,4\% в 2017 г.). Между тем, свыше 15\% в 2017 г. не доверяют ни одной общественной структуре. Живя в Дагестане не чувствуют себя в безопасности в 2007 г. 52\% населения, а в 2017 г. их доля увеличилась до 65,1\%. И если в 2007 г. всего 32\% респондентов считали жизнь в Дагестане безопасной, то за два года их доля заметно снизилась и составила в 2017 г. - 20,7\%.

Среднемесячный фактический душевой доход у 54,6\% семей в 2007 г. доставлял до 3000 руб. В 2017 г. их доля сократилась до 42,4\%. С 2007 г. по 2017 г. увеличилась доля семей, получающих доход 3000-5000 в среднем на одного человека. Даже это обстоятельство не помешало 65-70\% респондентам в указанные годы расценить материальное положение своих семьи как «семей среднего достатка» и «денег достаточно лишь на необходимые продукты и одежду». И при этом 41,4\% респондентов в 2017 г. считают, что для нормальной жизни их семей, доход на одного члена их семей должен составлять 10-20 тыс. руб., а в 2007 г. для основной массы опрашиваемых (36,4\%) была указана сумма от 5-10 тыс. руб. Такие массовые стихийные формы воздействия на политику властей принято называть национально-социальным протестом.

Возможность проведения массовых проте-

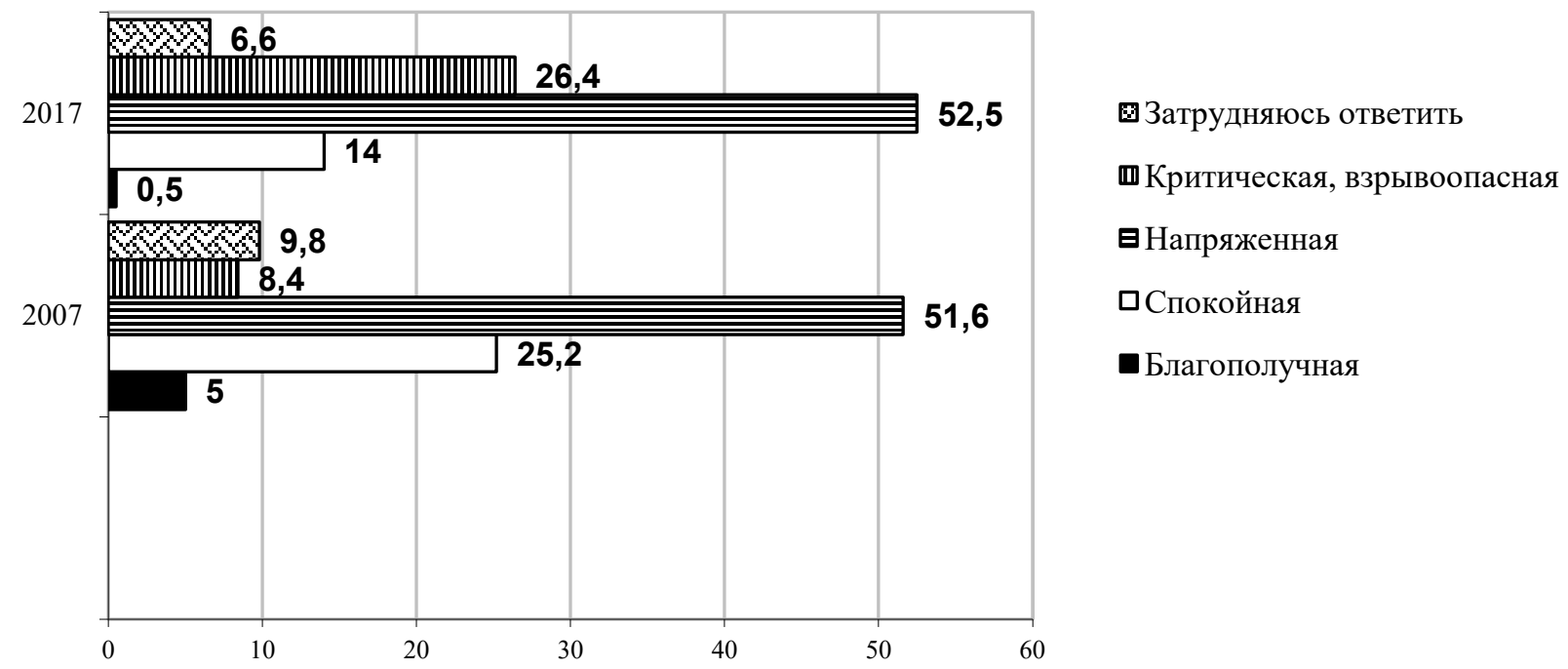

Puc. 1. Оценка респондентами политической обстановки в регионе Составлено автором по результатам проведенного исследования и исследования 2007 г. [2] 
стов против ухудшения жизненного уровня поддержали в 2007 г. - 32,\% населения, а в 2017 г.$22,4 \%$. Эта цифра сократилась почти в 2 раза по отношению к 2007 г. (см. табл. 1).

Теоретическую возможность участия в акции протеста признали в 2017 г. 22,4\% опрошенных, допуская тем самым возможность массовых акций протеста, поводом для которых может стать снижение уровня жизни населения, неправильные действия или бездействие власти. В 2017 г. результат социального протеста уменьшился по сравнению с 2007 г. в 1,6 раза. Свыше половины респондентов (75,1\% - в 2017 г. и 54,6\% - в 2007 г.) высказались против личного участия в каких-либо актах протеста.

Потенциальную склонность к протесту в наибольшей степени проявляют сельские жите- ли республики (табл. 2).

Несмотря на снижение показателей протестной активности с 30,4\% в 2007 г. до 15,3\% - в 2017 г. социальная напряженность, по-прежнему, остается довольно высокой вследствие низкого уровня жизни сельских жителей по сравнению городскими. Городские жители проявляют меньшую склонность к участию в акциях протеста.

В 2017 г. как и в 2007 г., среди жителей республики, идентифицирующих себя с «малообеспеченными и бедными», склонных к проявлению протестных настроений составляло большинство (в 2007 г.- 38,6\%, в 2017 г.- 33,7\%). Существенное снижение наблюдается среди людей «среднего достатка и богатых»: за 10 лет протестный потенциал снизился с 33,7\% в 2007 г. до

Таблица 1. Ответы респондентов на вопрос: «Как Вы считаете, могут ли состояться в вашем городе (районе) массовые выступления против роста цен и падения уровня жизни населения?»

\begin{tabular}{|c|c|c|}
\hline Варианты & 2007 г. & 2017 г. \\
\hline Да, и скорее да, чем нет & 36,8 & 22,4 \\
\hline $\begin{array}{l}\text { в том числе: «Вы лично примете участие в массовых высту- } \\
\text { плениях против роста цен и падения уровня жизни?» } \\
\text { - да } \\
\text { - нет } \\
\text { - затрудняюсь ответить }\end{array}$ & $\begin{array}{l}30,4 \\
54,6 \\
16,2\end{array}$ & $\begin{array}{c}15,3 \\
75,1 \\
9,6\end{array}$ \\
\hline Нет, и скорее нет, чем да & 49,2 & 50,9 \\
\hline Затрудняюсь ответить & 15,5 & 26,7 \\
\hline Итого & 100,0 & 100,0 \\
\hline
\end{tabular}

Примечание: Потенциал протеста составляют респонденты, ответившие «Да»на вопрос: Примите ли Вы личное участие в массовых выступлениях против роста цен и падения уровня жизни»?

Составлено автором по результатам проведенного исследования и исследования 2007 г. [2]

Таблица 2. Динамика потенциала протеста респондентов (в \%)

\begin{tabular}{|l|c|c|}
\hline \multicolumn{1}{|c|}{ Территории } & 2007 г. & 2017 г. \\
\hline По республике & 30,4 & 15,3 \\
\hline По городам & 27,2 & 9,4 \\
\hline По районам & 36,1 & 21,2 \\
\hline
\end{tabular}

Составлено автором по результатам проведенного исследования и исследования 2007 г. [2]

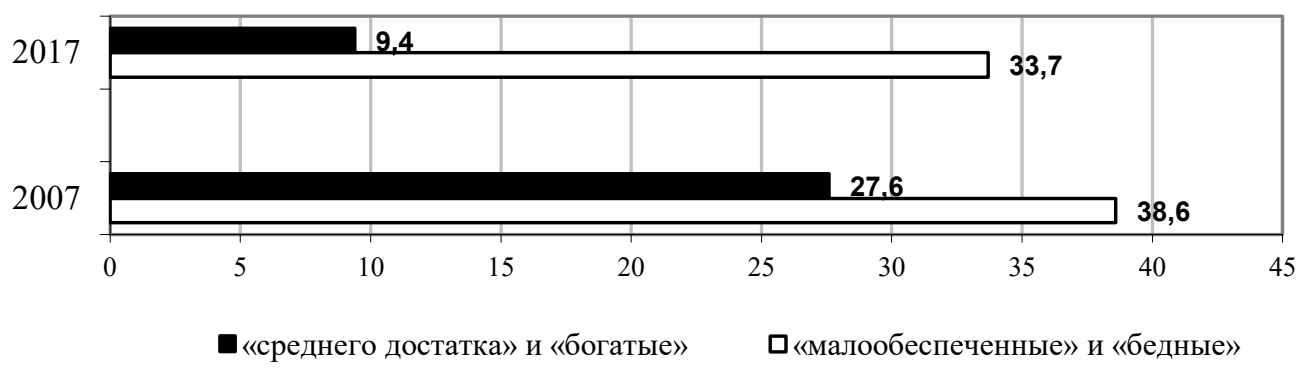

Puc. 2. Потенциал протеста в зависимости от социальной самоидентификации населения (доля «протестующих» от количества респондентов каждой категории,\%) Составлено автором по результатам проведенного исследования и исследования 2007 г. [2] 
9,4\% - в 2017 г. (рисунок 2).

Снижение протестных настроений среди различных категорий населения во многом обуславливается улучшением социального самочувствия населения в связи с мероприятиями властей по увеличению заработной платы, пенсий, социальных пособий работникам бюджетной сферы.

По сравнению с 2007 г. доля представителей «группы протеста» сократилась среди лиц, позитивно оценивающих свое эмоциональное состояние, с 32,1\% до 29,2\% - в 2017 г. А в группе жителей республики, испытывающих негативные эмоции, склонность к проявлению протестных настроений существенно не изменилась (35,3\% в 2017 г. против 34,8\% - в 2007 г.) (рисунок 3).

В 2017 г. доля представителей «протестной группы» осталась на прежнем уровне среди жителей региона, позитивно оценивающих курс экономических реформ, проводимых Президентом РФ (с 26,5\% в 2007 г. до 25,8\% в 2017 г.). Среди населения, неодобрительно характеризующего экономическую политику Главы государства и среди тех, кто относится к ней нейтрально, доля «протестующих» не изменилась - с 34,3\% в 2007 г. до 35,6\% в 2017 г. и с 32,6\% в 2007 г. до 33,8\% в 2017 г. (рисунок 4).

В 2017 г. склонность к протесту заметно сократилась среди жителей региона как «полностью и в основном одобряющих деятельность» (с 35,4\% в 2007 г. до 11,7\% в 2017.), так и «полностью и в основном не одобряющих» Главы Дагестана (в 2007 г. - Президента Республики Дагестан) (с 33,9\% до 62,1\%, соответственно). Доля «протестующих» значительно сократилась, среди тех, кто с «деятельностью не знаком» и «затруднился ответить» с 30,7\% - в 2007 г. до 26,2\% в 2017 г. (рисунок 5).

За рассматриваемый период уменьшилось число склонных к протесту среди респондентов, расценивающих политическую обстановку в регионе в целом как «благополучную» и «положительную» с 35,1\% - в 2007 г. до 18,4\% в 2017 г. В группе населения оценивающих политическую ситуацию как «напряженная, критическая и взрывоопасная», существенно возросла доля протестующих с 29,1\% до 42,9\% в 2017 г. (рисуНок 6).

Доля «протестующих» среди тех, кто считает, что Республику Дагестан ожидает «улучшение

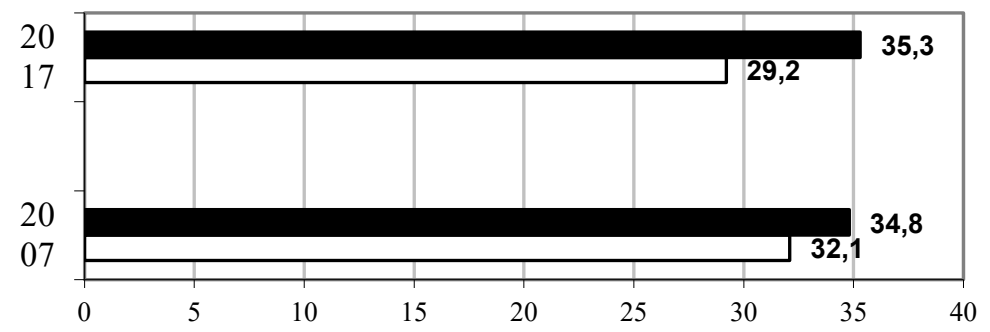

- Испытываю напряжение, раздражение, страх, тоску

口Прекрасное настроение, нормальное, ровное состояние

Puc. 3. Потенциал протеста в зависимости от оценок социального настроения (доля «протестующих» от общего количества респондентов каждой категории,\%) Составлено автором по результатам проведенного исследования и исследования 2007 г. [2]

2017

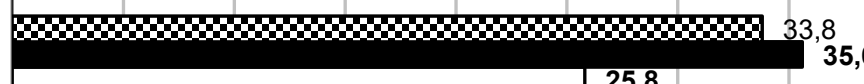

2007

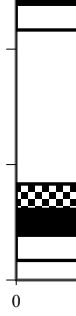

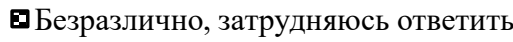 \\ В основном отрицательно \\ 口В основном положительно
}

Puc. 4. Уровень потенциала протеста в зависимости от оценок курса экономических реформ, проводимых Президентом РФ (доля «протестующих» от общего количества респондентов каждой категории, в\%)

Составлено автором по результатам проведенного исследования и исследования 2007 г. [2] 


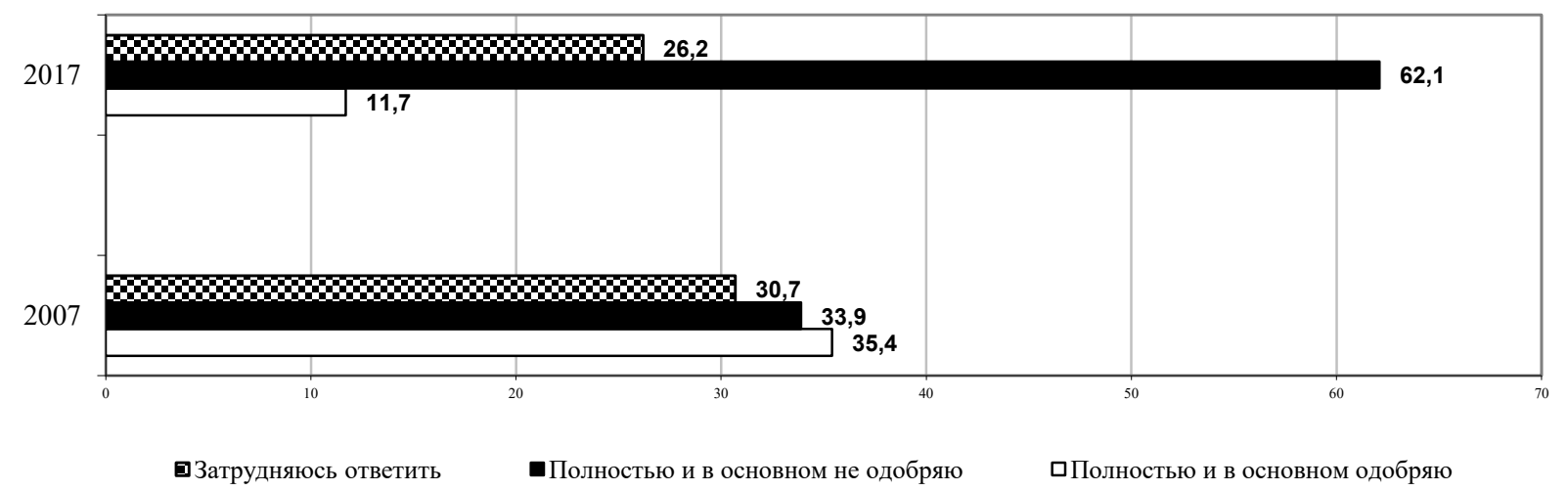

Puc. 5. Уровень потенциала протеста в зависимости от оценок деятельности Главы РД (2017 г.) и Президента РД (2007 г.) (доля «протестующих» от общего количества респондентов каждой категории, в\%)

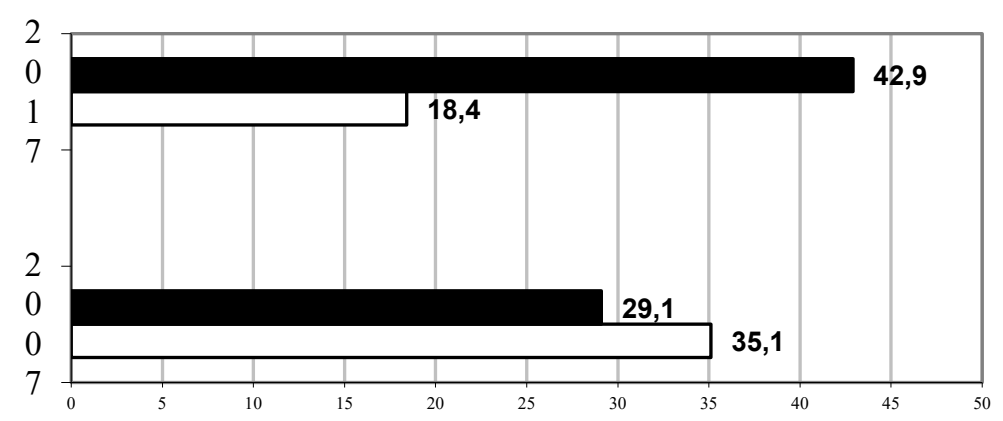

\author{
«Напряженная», \\ «критическая, \\ взрывоопасная» \\ 口«Благополучная», \\ «положительная»
}

Puc. 6. Уровень потенциала протеста в зависимости от оценок политической ситуации в регионе (доля «протестующих» от общего количества респондентов каждой категории, в\%)

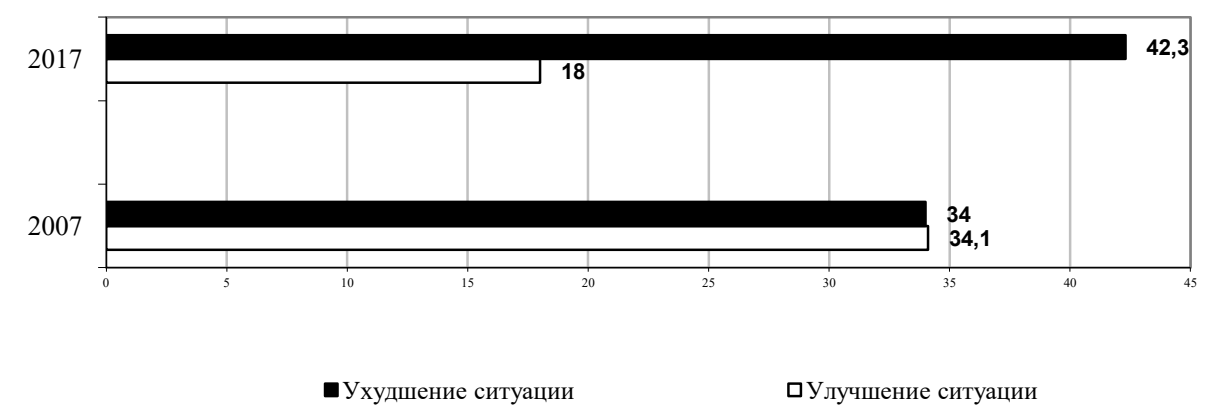

Puc. 7. Уровень потенциала протеста в зависимости от оценок перспектив политической жизни региона (доля «протестующих» от общего количества респондентов каждой категории, в\%)

ситуации» в ближайшее время в политической жизни снизилась с 34,1\% - в 2007 г. до 18,0\% - в 2017 г., а тех, кто считает, что республику ожидает «ухудшение ситуации» в политической жизни увеличилась с 34\% - в 2007 г. до 42,3\% - в 2017 г. (рисунок 7).

Кроме того, большинство респондентов (в среднем свыше 50\%, (в 2007 г. их доля составляла $-54,6 \%)$ считают, что спокойствие в регионе является большой ценностью, ради которой можно терпеть определенные материальные трудности. Следует отметить, что при явном доминировании причин, побуждающих к протесту, и серьезном ущемлении насущных жизненных интересов, большинство населения сохраняет здравый смысл и выдержку, которая позволяет Дагестану пережить трудный в социально-экономическом плане период развития экономики без массовых социальных взрывов.

Таким образом, протестный потенциал в 
Республике Дагестан с 2017 г.(15,3\%) хоть и снизился в сравнении с 2007 г (30,4\%), но по многим позициям обществом высказано крайне неодобрительное отношение ко всей социально-экономической ситуацией в регионе, к курсу проводимых экономических преобразований проводимой властью Республики Дагестан.

О своей готовности поддержать акции протеста в 2017 г. чаще других заявляли жители региона, отличающиеся негативными оценками своего экономического положения и социального самочувствия (около 30\%), а также неодобрительно оценивающие деятельность общественных структур и властей (свыше 35\%). Однако в сравнении с 2007 г. удельный вес «протестующих» в соответствующих категориях населения заметно сократился. Дальнейшие изменения протестных настроений в регионе будут зависеть от эффективности мероприятий властных структур различных уровней, направленных на улучшение социально-экономического положения населения.

Выводы. Достаточно очевидно, что ситуация в Республике Дагестан, далеко не радужная. И результаты проведенного обследования сви- детельствуют об обеспокоенности и недовольстве людей в целом социально-экономической ситуацией в регионе. Люди не готовы принимать участие в митингах и акциях протеста. Но если проанализировать ту часть населения, которая может принять участие в акциях протеста, то можно сказать, что здесь люди пойдут, и будут протестовать не против нынешней власти, а будут выступать против сложившейся социально-экономической ситуации. Поэтому можно сказать, что если акции протеста и будут иметь место, то это будут протесты, связанные с ухудшением социально-экономической ситуации в регионе.

Для своевременного выявления «проблемных точек» в социально-экономической региональной политике на ранних стадиях представляется целесообразным проведение независимых регулярных мониторингов. Результаты анализа данных таких мониторингов существенно повысят информативность и эффективность решений органов государственной власти, направленных на локализацию и устранение причин, способных послужить основанием для открытого протестного поведения населения.

\section{Библиографический список}

1. Регионы России. Социально-экономические показатели. 2017: Р32. Стат. сб. / Росстат. М., 2017. - 1402 с.

2. Хаджалова Х.М. Потенциал социального протеста в Республике Дагестан //Народонаселение. 2008 . № 1. C. $139-145$.

3. Хаджалова Х.М. Об измерении социальной напряженности (на материалах Республики Дагестан) // Труд и социальные отношения. 2008. № 7. С. 119-127.

4. Хаджалова Х.М. Основные направления повышения качества жизни населения и снижения социальной напряженности в Республике Дагестан // Региональная экономика: теория и практика. 2010. № 3. С. 35-38.

5. Хаджалова Х.М. Корреляционная зависимость качества жизни населения и социальной напряженности // Региональные проблемы преобразования экономики. 2012. № 2. С. 286-294. 
ЭКОНОМИКА. ЭКОНОМИЧЕСКИЕ НАУКИ

\section{ЭКОНОМИЧЕСКАЯ ТЕОРИЯ}





\title{
НЕЗАСЛУЖЕННОЕ ОБВИНЕНИЕ В ЭКОНОМИЧЕСКОМ ДЕТЕРМИНИЗМЕ, И ПОЧЕМУ Ф. ЭНГЕЛЬС НЕ РАСКРЫЛ МЕТОД К. МАРКСА
}

\author{
(C) 2018 Лебедев Константин Николаевич \\ доктор экономических наук, профессор Департамента экономической теории \\ Финансовый университет при Правительстве Российской Федерации \\ 125993, г. Москва, Ленинградский пр-т, д. 49 \\ E-mail: KNLebedev@fa.ru
}

В настоящей статье показывается, что из метода диалектического материализма, которым К. Маркс пользовался при создании своих теорий экономического и социального развития, вовсе не следует, что если способ производства определяет надстройку, то надстройка не оказывает обратного воздействия на способ производства, и они оба вместе не определяют развитие общества, в связи с чем К. Маркс был незаслуженно обвинен в экономическом детерминизме. При этом показывается, что метод диалектического материализма является неадекватным методом социально-экономического исследования, основанным на приписывании социально-экономическим системам законов развития организмов, в связи с чем на его основе и был получен неверный вывод о неизбежной исторической победе социализма над капитализмом.

Ключевые слова: экономический детерминизм, диалектический материализм, закон взаимодействия содержания и формы.

Для справедливой оценки творческого наследия К. Маркса необходимо, в частности, иметь правильное представление о методе исследования, которым он пользовался. Знание этого метода помогает правильно интерпретировать некоторые высказывания К. Маркса, смысл которых в свое время был повернут против него. Одним из таких высказываний стало высказывание «бытие определяет сознание», результатом неверной интерпретации которого стали обвинения К. Маркса в так называемом экономическом детерминизме, а его экономическое объяснение истории в конце XIX в. было признано ложной теорией.

K сожалению, для реабилитации Марксова экономического объяснения истории, или экономического детерминизма, придется вскрыть причины неадекватности главного положения его теории социально-экономического развития, а именно положения об исторической победе социализма над капитализмом, которая стала очевидной в начале 90-х гг. XX в. после возврата основной массы стран социализма к капитализму. При этом весь необходимый для настоящего исследования эмпирический материал заключен в отрывке из «Предисловия» его работы «К критике политической экономии» (1859), выступающий наиболее цитируемой частью Марксова творческого наследия. Это неудивительно, так как сам К. Маркс назвал его «Общий резуль-

тат, к которому я пришел и который послужил затем руководящей нитью в моих дальнейших исследованиях». Это следующие слова К. Маркса: «В общественном производстве своей жизни люди вступают в определённые, необходимые, от их воли не зависящие отношения - производственные отношения, которые соответствуют определённой ступени развития их материальных производительных сил. Совокупность этих производственных отношений составляет экономическую структуру общества, реальный базис, на котором возвышается юридическая и политическая надстройка и которому соответствуют определённые формы общественного сознания. Способ производства материальной жизни обусловливает социальный, политический и духовный процессы жизни вообще. Не сознание людей определяет их бытие, а, наоборот, их общественное бытие определяет их сознание. На известной ступени своего развития материальные производительные силы общества приходят в противоречие с существующими производственными отношениями, или - что является только юридическим выражением последних - с отношениями собственности, внутри которых они до сих пор развивались. Из форм развития производительных сил эти отношения превращаются в их оковы. Тогда наступает эпоха социальной революции. С изменением экономической основы более или менее быстро 
происходит переворот во всей громадной надстройке. При рассмотрении таких переворотов необходимо всегда отличать материальный, с естественно-научной точностью констатируемый переворот в экономических условиях производства - от юридических, политических, peлигиозных, художественных или философских, короче - от идеологических форм, в которых люди осознают этот конфликт и борются за его разрешение» [1, с. 6-7]. Именно в этом отрывке содержится высказывание К. Маркса, благодаря которому он был обвинен в экономическом детерминизме, т.е. в сведении всех факторов развития общества к одному, которым является экономика.

Критики К. Маркса справедливо утверждали, что экономический фактор есть лишь один из факторов, взаимодействующих в общественном процессе, что неоспоримо, так как одной из общепризнанных особенностей социальных процессов является множественность и одновременное действие их факторов. Они справедливо утверждали, что экономика не только взаимодействует с другими социальными факторами (религией, моралью, правом, философией, искусством), вместе определяя развитие общества, но и испытывает на себе их воздействие. Более того, критики К. Маркса находили в работах К. Маркса, а также Ф. Энгельса, множество мест, в которых классики марксизма и признают обратное влияние прочих социальных факторов на экономику.

При этом ученые, обвинявшие К. Маркса в экономическом детерминизме, также обвиняли его в абсолютной бездоказательности этого учения. Вот как пишет об этом А. Боровой, кстати, сторонник марксизма в остальной части марксистской теории, в «Популярном курсе политической экономии» (1908): «Главное, что может быть поставлено в упрек теории, это - то, что она является совершенно голословной. Во всей литературе марксизма мы не найдем сколь-нибудь удовлетворительного ее обоснования. Все доказательства в ее пользу сводятся обычно к более или менее удачным историческим иллюстрациям, которые должны подчеркнуть особую важность экономического фактора» [2, с. 14].

Что интересно, сам Ф. Энгельс, популяризатор и толкователь К. Маркса, не мог сказать ничего более основательного в защиту марксизма от обвинений в экономическом детерминизме, кроме следующих слов, представленных в одном из его писем: «Мы должны были ввиду противников настаивать на отрицаемом главном принципе, и не всегда имели время, место и повод указывать на остальные, участвующие во взаимодействии моменты...» [цит. по 2, с. 14]. В связи с этим данные слова Ф. Энгельса даже интерпретировались критиками, например тем же А. Боровым, как признание ошибочности вменяемой марксизму доктрины [2, с. 14]. Как соответствующее признание интерпретировались и слова «наиболее слепого поклонника экономического материализма» Г.В. Плеханова: «... Взаимодействие бесспорно существует между всеми сторонами общественной жизни» [цит. по 2, с. 14-15].

Вначале посмотрим на метод, посредством которого К. Марксом была сформирована изложенная в приведенном выше отрывке теория экономического и социального развития. Наиболее ясно он виден при изложении теории экономического развития, т.е. развития способа производства. Не сложно понять, что она сформирована на основе закона взаимодействия содержания и формы, входящего в состав диалектического материализма. Напомним, что основу этого философского учения составляют философские законы, а именно 3 собственно закона диалектики (перехода количественных изменений в качественные и обратно, единства и борьбы противоположностей и отрицания отрицания) и законы взаимодействия взаимосвязанных философских категорий (сущности и явления, исторического и логического, содержания и формы, единичного, особенного и всеобщего, причины и следствия и т.д.). Закон взаимодействия содержания и формы хорошо сформулирован в «Кратком философском словаре» (1954): «Всякий предмет, всякое явление в природе и обществе имеет свое содержание и свою форму... Диалектический материализм рассматривает форму и содержание в единстве, в котором определяющим является содержание... Содержание, развитие содержания всегда предшествует возникновению и развитию формы... Форма активно воздействует на содержание, содействуя или тормозя его развитие... Единство содержания и формы не исключает противоречий между ними... В процессе своего развития содержание предмета вступает в противоречие, в борьбу со старой формой, уже не соответствующей новому содержанию; противоречие это разрешается путем уничтожения, сбрасывания новым содержанием устаревшей формы... Новое содержание 
породило новую форму...» [3, с. 644-645].

Производительные силы в теории развития экономики выступают содержанием последней, а производственные отношения - ее формой. В соответствии с законом взаимодействия содержания и формы производительные силы определяют производственные отношения, приводя к смене последних всякий раз, как они перестают соответствовать производительным силам. При этом производительные силы развиваются эволюционно, а производственные силы - peволюционно, т.е. их смена происходит в результате революции. Важно отметить, что развитие способа производства зависит и от производственных отношений, которые могут как способствовать (в максимальной степени - после смены), так и препятствовать (в максимальной степени - перед очередной сменой) развитию его содержания, т.е. производительные силы и производственные отношения вместе влияют на развитие способа производства. Обратим внимание на то, что то, что производительные силы определяют производственные отношения, вовсе не означает, что последние не оказывают влияния на первые.

Понимание того, что теория развития общества К. Маркса также сформирована на основе закона взаимодействия содержания и формы, позволяет снять с К. Маркса и марксистской теории социального развития всякие обвинения в экономическом детерминизме. Слова «бытие определяет сознание», или, что в данном случае то же самое, что способ производства определяет надстройку, в рамках этого закона вовсе не означают, что способ производства, или экономика, является единственным фактором развития общества. В соответствии с данным законом надстройка оказывает активное обратное воздействие на способ производства, способствуя или замедляя его развитие и, следовательно, способ производства и надстройка, взаимодействия друг с другом, совместно определяют развитие общества. Таким образом, понимание того, что в основе Марксовой теории развития общества лежит закон взаимодействия содержания и формы, позволяет правильно интерпретировать слова К. Маркса о том, что бытие определяет сознание, или способ производства определяет надстройку, в связи с чем с К. Маркса снимаются абсолютно необоснованные обвинения в экономическом детерминизме.

Избавление марксизма от незаслуженных обвинений путем раскрытия метода формирования теории общественного развития, к сожалению или к счастью, приводит к выявлению такой проблемы марксизма, как использование неадекватного метода исследования, которое привело к теперь уже очевидным образом неверному и, скорее всего, заранее заданному выводу о победе социализма над капитализмом. Напомним, что этот вывод основан на том, что развитие производительных сил при капитализме приобретает общественный характер, выражающийся в концентрации средств производства и рабочей силы на крупных предприятиях, усилении взаимосвязи и взаимозависимости между предприятиями, отраслями и т.д. Такой же характер (общественный, или социалистический) должны иметь и соответствующие им производственные отношения, в том числе отношения собственности.

Неадекватность закона соответствия содержания и формы, на основе которого сделан вывод о скорой и неизбежной смене капиталистических производственных отношений социалистическими в результате пролетарской революции, как метода исследования обусловлена тем, что этот закон, как и все законы диалектики, рекрутирован из мира организмов, т.е. выступает биологической аналогией, или отражением свойств организмов [4]. Проблемой же приписывания свойств организмов социально-экономическим объектам как метода исследования является то, что они далеко не всегда соответствуют свойствам последних, в связи с чем использование данного метода познания чревато получением неверных выводов [5, с. 14]. Биологическое происхождение законов диалектики хорошо видно, в частности, из такого произведения Ф. Энгельса, как «Анти-Дюринг» (1876-1878). Так, закон отрицания, который был использован К. Марксом для «открытия» закона развития капиталистической собственности (от экспроприации непосредственных производителей капиталистами до экспроприации экспроприаторов), Ф. Энгельс обосновывает на примере развития ячменного зерна [6, с. 104-106].

Неадекватность диалектического материализма как метода экономического исследования состоит и в произвольном характере отнесения изучаемых социально-экономических явлений к категориям используемых философских законов.

Как пишет Ю.И. Будович в статье «Курс 
отечественной политэкономии середины XIX - начала XX в. о методе экономического исследования», «методом получения выводов стала зачастую искусственная подгонка хозяйственных явлений под категории философских законов с нужным следствием. Так, на основании философского закона соответствия формы содержанию в науке делался вывод о том, что развитие производительных сил неизбежно потребует общественной собственности на средства производства. Для его доказательства необходимо было лишь объявить рост масштабов производства и взаимозависимости между отдельными частями экономики усилением общественного характера производительных сил, а отношения собственности назвать формой, в которой происходит это развитие» [7, с. 84]. Почему, если признаком отнесения к форме фактически выступает революционность изменения какого-то явления, то К. Маркс отнес к форме развития способа производства производственные отношения, а не производительные силы? Уже в его времена было достаточно исторического материала для того, чтобы заключить, что производительные силы развиваются не менее, а даже более революционно, чем производственные отношения. Если ко времени жизни К. Маркса произошли только две революции в производственных отношениях (при переходе от рабовладения к феодализму и от феодализма к капитализму), то таковых в производительных силах произошло по крайней мере три: 1) переход в промышленности на разделение труда по принципу «одно движение - одна работа», с описания которого (рост производительности в 240 раз!) начинает свое «Богатство народов» А. Смит (1776) [8, с. 10-11], 2) переход к новым технологиям производства текстиля и чугуна на повышательной волне 1-го цикла Н.Д. Кондратьева (1787-1792)-(1810-1817) гг., 3) бурное развитие железных дорог, освоение территории США, преобразование сельского хозяйства на повышательной волне 2-го цикла Н.Д. Кондратьева (1844-1851)-(1870-1875) гг.) [9, с. 449]. Но К. Маркс отнес к форме развития способа производства именно производственные отношения, так как это нужно было для того, чтобы обосновать его «революционный» вывод [10].

Следует отметить, что регулятор советской политической экономии, возможно именно для того, чтобы исследователи не занялись реабилитацией Марксова учения о социальном разви- тии в связи с его обвинениями и экономическом детерминизме и в ходе этого процесса не обратились к методу, использованному К. Марксом, и не вскрыли его органическую и произвольную сущность, решил внести уточнение в Марксову мысль из «Предисловия» книги «К критике политической экономии» (1859), обязав формулировать предмет науки следующим образом: «Политическая экономия изучает производственные отношения в их единстве и взаимодействии с производительными силами и надстройкой» [11, с. 48].

Выяснение органического характера метода, использованного К. Марксом для формирования его теорий экономического и социального развития, позволяет установить, почему же Ф. Энгельс так вяло ответил на обвинения в адрес К. Маркса в экономическом детерминизме. Как не ему следовало бы объяснить критикам, что в рамках использовавшегося К. Марксом для формирования его теории развития общества закона взаимодействия содержания и формы выражение «способ производства определяет надстройку» вовсе не означает, что надстройка не определяет развитие общества и не оказывает обратного влияния на развитие способа производства. Но Ф. Энгельс, очевидно, прекрасно понимал уязвимость органической методологии, использованной К. Марксом, факт применения которой вскрылся бы при подобном объяснении. Дело в том, что всего через пять лет после завершения им работы над «Анти-Дюрингом» вышла книга основателя австрийской школы политической экономии К. Менгера «Исследование о методах социальных наук и политической экономии в особенности» (1883), в которой органицизм в социальном исследовании был подвергнут сокрушительной критике. При этом Ф. Энгельс до своего ухода из жизни (1820-1895) имел возможность с этой книгой хорошо ознакомиться. К. Менгер, в частности, указал причины неадекватности органического подхода к исследованию социальных явлений: «Во-первых, лишь некоторая часть социальных явлений обнаруживает аналогию с естественными организмами... Во-вторых, аналогия между социальными явлениями и естественными организмами, даже там, где о таковой... и может быть речь, не бывает полной, объемлющей все стороны существа известных явлений...» [12, с. 390]. Фактически эти слова были предназначены Ф. Энгельсу, выступившему теоретиком органицизма в соци- 
ально-экономическом исследовании.

\section{Библиографический список}

1. Маркс К. и Энгельс Ф. Соч. Изд.2-е. Москва. 1959. 771 [XXVI] с.

2. Боровой А. Популярный курс политической экономии. Москва. 1908. 326 с.

3. Краткий философский словарь / Под ред. М. Розенталя и П. Юдина. Москва. 1954. 704 с.

4. Лебедев К.Н. Механистические и организмические модели экономических процессов и проблемы экономической науки в современной российской экономической теории и его сущность //Вестник Финансовой академии. 2009. № 5. С. 47-53.

5. Лебедев К.Н. Метод науки в современной российской экономической теории и его сущность // Экономические науки. 2014. № 9 (118). С. 12-16.

6. Энгельс Ф. Анти-Дюринг. Переворот в науке, произведенный господином Евгением Дюрингом. Москва. 1978. 358 c.

7. Будович Ю.И. Курс отечественной политэкономии середины XIX - начала XX в. о методе экономического исследования // Вестник Финансовой академии. 2004. № 1. С. 78-86.

8. Смит А. Исследование о природе и причинах Богатства народов. Книга первая. Москва. 1997. 256 с.

9. Курс экономической теории / Под. ред. М.Н. Чепурина и Е.А. Киселевой. Киров: АСА, 2007. 848 с.

10. Будович Ю.И. Марксистская трактовка предмета науки как производственных отношений и ее недостатки // Проблемы развития современного общества: экономические, правовые и социальные аспекты. Сб. науч. статей по итогам Всероссийской научно-практической конференции. Под редакцией И.Е. Бельских, А.Ф. Московцева. 2014. С. 57-63.

11. Медведев В.А., Абалкин Л.И., Ожерельев О.И. и др. Политическая экономия: Учебник. Москва. 1989.735 с.

12. Менгер К. Избранные работы. Москва. 2005. 496 с. 


\title{
ОБЛАДАЛ ЛИ К. МАРКС ЭКОНОМИЧЕСКИМ ВЗГЛЯДОМ НА ХОЗЯЙСТВЕННУЮ ДЕЯТЕЛЬНОСТЬ?
}

\author{
(C) 2018 Будович Юлия Ивановна \\ доктор экономических наук, профессор Департамента экономической теории \\ Финансовый университет при Правительстве Российской Федерации \\ 125993, г. Москва, Ленинградский пр-т, д. 49 \\ E-mail: JBudovich@fa.ru
}

В настоящей статье рассматриваются причины, побуждавшие советскую политическую экономию избегать конкретики при освещении такой темы, как производственные отношения, в том числе отношения собственности, показывается, как истина в вопросе о том, кому принадлежат средства производства, приносилась в жертву политическим и идеологическим устремлениям, не взирая ни на какие социально-экономические последствия.

Ключевые слова: производственные отношения, отношения собственности, собственность на средства производства, собственность на капитал.

В советской политической экономии самой «загадочной» экономической категорией были производственные отношения, и это при том, что производственные отношения были фактически главной категорией науки, так как фигурировали в качестве ее предмета. Загадочность производственных отношений состояла в отсутствии их конкретных примеров. В учебниках давалось общее определение производственных отношений (отношения, в которые независимо от их воли и сознания вступают люди в процессе материального производства), рассказывалось, чем производственные отношения при социализме отличаются от производственных отношений при капитализме (при социализме, когда средства производства находятся в руках общества, они являются отношениями сотрудничества и взаимопомощи, тогда как при капитализме, когда средства производства принадлежать частным лицам, они являются отношениями эксплуатации человека человеком), отмечалось, что производственные отношения являются формой развития производительных сил, указывалось, что основой системы производственных отношений выступают отношения собственности на средства производства и что последние пронизывают все сферы экономических отношений (производство, распределение, обмен, потребление) и т.д., но нигде не приводились конкретные примеры производственных отношений, хотя бы отношений собственности как главных из них и поэтому в первую очередь уничтожаемых в ходе социальных революций. При этом все делали вид, что ясно себе пред-

ставляют, что такое производственные отношения, намекали, что спрашивать, что этот такое, просто неприлично. Удивительно, но в условиях, когда нельзя было оперировать примерами производственных отношений, в науке даже шла дискуссия о структуре производственных отношений социализма.

Как выясняется, туманность категорий марксистской экономической теории всегда была характерной чертой данной теории, и она отмечалась даже теми учеными, которые разделяли многие ее положения, например трудовую теорию стоимости. Как писал, например Л. Боровой в своем «Популярном курсе политической экономии» (1908): «Маркс, Энгельс и их последователи постоянно употребляют термины «производственные отношения», «способы производства», «условия производства» или «надстройка», «отражение», «рефлекс», нигде не давая их удовлетворительного объяснения, нигде не поясняя самой природы отношений между «бытием» и «сознанием», между «базисом» и «надстройкой» и т.д. и т.д. Эта уже одна невыясненность терминологии подает повод к многочисленным недоразумениям и своеобразным толкованиям доктрины» [2, с. 14]. М.И. Туган-Барановский в своих «Основах политической экономии» (1911) критикует классиков марксизма за непоследовательность в трактовке хозяйственной жизни: «Под экономическими отношениями, которые мы признаем определяющей основой общества,- пишет Энгельс в 1894 г., в одном из впоследствии опубликованных писем,- мы понимаем способ, которым люди определенно- 
го общества производят свои средства к жизни и обмениваются ими» (Documente des Socialismus, 1902, T. II, с. 73), а под средствами к жизни Энгельс понимает, как видно из его «Происхождения семейства», «пищу, одежу, жилье и необходимые для этого средства труда» (Engels, Der Ursprung der Familie, 8 изд., Предисл., с. VIII)» [3, с. 4]. Как отмечает далее М.И. Туган-Барановский, «правда, Энгельс не выдерживает этого определения и нередко сходит с его почвы. Производство товаров следует считать, с точки зрения Маркса и Энгельса, безусловно хозяйственной деятельностью, но товарами являются предметы, удовлетворяющие далеко не одним необходимым потребностям жизни. Библия в известном примере Маркса в I томе «Капитала» есть такой же товар, как и холст или водка» [3, с. 4]. При этом после перехода в нашей стране на рубеже 20-30-х гг. $\mathrm{XX}$ в. к марксистско-ленинской политической экономии советские толкователи марксизма разъяснили его основные понятия (способ производства, надстройка и т.д.), но термин «производственные отношения» так и оставили загадкой [4] [5]. Выяснению конкретного содержания данного понятия, прежде всего отношений собственности, и причин, побуждавших регулятора советской политической экономии его скрывать, и посвящается данная статья.

Подходом к решению поставленных задач является общепризнанное положение, что языком экономики является бухгалтерский учет [6]. М.С. Атлас и К.Н.Лебедев в статье «К вопросу о содержании экономических понятий» (2000) фактически показали, что содержание экономических понятий, используемых для изучения деятельности предприятия, образуют приходы и расходы средств предприятия (его активов) и их источников (его пассивов), а также их запасы [7]. Первые образуют содержание бухгалтерской отчетности, характеризующей объемы деятельности предприятия в течение отчетного периода, а вторые образуют содержание бухгалтерского баланса, характеризующего состояние предприятия на конец периода. Таким образом, экономическую картину деятельности хозяйства, или предприятия, дают бухгалтерские отчетность и баланс или, по-другому, экономист видит хозяйственную деятельность в виде бухгалтерских отчетности и баланса. Очевидно, что с помощью отчетности и баланса можно продемонстрировать отличие экономического взгляда на предприятие от технического взгляда на него, т.е. взгляда, характерного для техника. В соответствующих целях, в виду его большей простоты, используем только баланс. В табл. 1 представлен бухгалтерский баланс предприятия (без цифровых данных), в котором жирным и курсивом выделены позиции, доступные взгляду техника.

Таким образом, техник не увидит в хозяйственной деятельности все пассивы предприятия и такой его актив, как задолженность предприятию, или, по-другому, увидит только реальные ценности предприятия, но не фиктивные. Это объясняется тем, что технические работники, в том числе кассир, отвечающий за хранение денег предприятия, не осуществляют расчетов с организациями, с которыми связано предприятия. А именно при осуществлении расчетов (с покупателями, учредителями, банками-кредиторами, продавцами) у предприятия и возникают фиктивные ценности.

Теперь будет легко ответить на вопрос, обладал ли К. Маркс экономическим взглядом на хозяйственную деятельность, законы которого пытался установить? В работе К.Н. Лебедева «Почему модель кругооборота капитала К. Маркса так и не стала теорией бухгалтерского учета» (2015) показано, что Марксова модель кругооборота капитала «Деньги - Товар (средства производства, рабочая сила)... Производство... Товар штрих (готовая продукция) - Деньги штрих» (Д - Т (Сп, Рс) ...П... Т’ - Д’) не стала моделью деятельности по бухгалтерскому учету прежде всего потому, что в ней не представлена такая

Таблица 1. Бухгалтерский баланс, и его часть, которую видит техник

\begin{tabular}{|l|l|}
\hline \multicolumn{1}{|c|}{ АКТИВ } & \multicolumn{1}{|c|}{ ПАССИВ } \\
\hline Средства труда & Капитал \\
\hline Предметы труда & Прибыль \\
\hline Незавершенное производство & Кредиты полученные \\
\hline Готовая продукция & Задолженность предприятия \\
\hline Деньги & \\
\hline Задолженность предприятию & \\
\hline
\end{tabular}

Источник: составлено автором. 
обязательно представленная на предприятии форма стоимости, как имущество капиталиста, которая уменьшается при вложении капиталистом средств в предприятие, в том числе в форме нераспределенной прибыли, и увеличивается при изъятии вложенных в бизнес средств и распределении прибыли. Данная форма стоимости, т.е. имущество капиталиста, как раз и получает отражение в пассиве баланса, т.е. является пассивами предприятия (капитал и прибыль). В модели нет и форм стоимости, соответствующих другим фиктивным ценностям, образующим активы или пассивы предприятия [8, с. 49]. Соответственно, все представленные в Марксовой модели кругооборота капитала формы стоимости, а именно денежная, товарная и производственная, относятся исключительно к реальным ценностям. В связи с этим, как отмечается в рассматриваемой статье, модель кругооборота капитала в действительности является моделью кругооборота не капитала, а средств, вложенных в деньги предприятия [8, с. 49]. Никакого капитала в этой модели не представлено. Таким образом, судя по модели кругооборота капитала, можно утверждать, что К. Маркс не обладал экономическим взглядом на хозяйственную деятельность, так как не замечал фиктивных ценностей предприятия, образующих его пассивы и частично - активы.

Подтверждает вывод об отсутствии у К. Маркса экономического взгляда на хозяйственную деятельность, сделанный на основе сравнения форм стоимости, представленных в его модели кругооборота капитала, с формами стоимости, получающими отражение в бухгалтерском балансе, и сведения о знании К. Марксом бухгалтерского учета, в котором составляется баланс. Целая глава книги К.Ю.Цыганкова «Очерки теории и истории бухгалтерского учета» (2007) посвящена исследованию познаний в области бухгалтерского учета классиков марксизма, в том числе на основе изучения их переписки по данному вопросу, в которой К. Маркс задает коммерсанту Ф. Энгельсу разные вопросы, касающиеся ведения бухгалтерского учета, а Ф. Энгельс никак не может на них ответить, и оба признаются в слабом понимании сути бухгалтерии. Так, по вопросу о фонде возмещения основного капитала Ф. Энгельс обещает прислать К. Марксу расчеты и признается: «Что же касается экономического значения этого дела, то оно мне не совсем ясно» [9, с. 308]. Из всего этого он делает следующий вывод: «... И К. Маркс, и Ф. Энгельс, даже не имея практического опыта, могли, работая с литературой совершенно самостоятельно, быстро ухватить суть любой науки и технологии, составить о ней независимое, самостоятельное мнение, публиковать и успешно отстаивать его в дискуссиях с профессионалами. Бухгалтерия стала для них исключением...» [9, с. 309]. Таким образом, исследование К.Ю. Цыганкова подтверждает сделанный ранее вывод о том, что К. Маркс не обладал экономическим взглядом на хозяйственную деятельность.

Как было показано выше, отсутствие экономического взгляда на хозяйственную деятельность фактически означает, что соответствующее лицо не видит такой части экономической реальности, как пассивы. Это значит, что понятия или термины, используемые для характеристики пассивов, он применяет к активам, в связи, с чем возникает терминологическая путаница. Ярким примером такой путаницы является применение к активам названия «Капитал», служащего для обозначения определенных пассивов. Соответствующее неправильное словоупотребление как раз имело место в переписке между К. Марксом и Ф. Энгельсом по вопросам ведения бухгалтерского учета. В ней фонд возмещения основных средств, или средств труда, именуется классиками марксизма фондом возмещения основного капитала, т.е. основные средства они путают с основным капиталом. Об этой распространенной путанице, характерной, кстати, для ученых-экономистов, писал американский экономист Дж.Б. Кларк в знаменитом произведении «Распределение богатства» (1899): «Капитал делится на основной и оборотный. Этими терминами обычно обозначаются различные части перманентного фонда истинного капитала, а не два вида капитальных благ; и обычная мысль и разговорная речь чаще всего употребляют их в этом смысле... Но в научном использовании эти термины употребляются для выражения двух разновидностей капитальных благ. И здесь в результате снова получается известная путаница... Определенные виды средств производства, как нам говорят экономисты, являются основным капиталом, а некоторые другие вещи - оборотным капиталом. Строения, машины и т.п. представляют первый род; сырье, полуфабрикаты и т.д.- последний» [10, с. 126]. Собственно говоря, само название модели «Модель кругооборота капитала» говорит о том, что ее автор понимал под 
капиталом средства и предметы труда, товары и деньги.

Далее мы вплотную приближаемся к разгадке тайны производственных отношений, включая отношения собственности. Те отношения собственности при капитализме, которые имеют социальное содержание и уничтожаются в результате пролетарской революции, получают отражение в пассиве баланса. Это отношения собственности на капитал, который, будучи внесенным в предприятие капиталистами в виде учредительских взносов или ссуд, становится долгом предприятия, т.е. образует его пассив. К. Маркс, как было показано выше, видел только актив предприятия и, следовательно, только те отношения собственности, которые получают отражение в активе баланса. А это отношения собственности предприятия на принадлежащие ему основные средства, материалы, готовую продукцию, деньги и т.д., т.е. отношения собственности предприятия на средства производства. В связи с тем, что К. Маркс видел только актив предприятия, то понятие «собственность на капитал» ассоциировалось у него с собственностью предприятия на средства производства. В связи с этим К. Маркс говорил об изъятии у капиталистов не вкладов и взносов в предприятия, а именно средств производства, как расшифровывалось понятие «экспроприация экспроприаторов» [11]. Поэтому, приводя примеры отношений собственности, советским политэкономам пришлось бы приводить примеры приобретения, владения и распоряжения предприятиями своими активами, которые не имеют никакого отношения к тому, что получают в собственность, чем владеют и распоряжаются капиталисты. Но в этом случае вскрылось бы несоответствие марксистско-ленинской политической экономии экономической реальности и, соответственно, экономическое невежество К. Маркса. Теперь ясно, и почему не приводились примеры других производственных отношений. Дело в том, что отношения приобретения предприятиями реальных активов (средств производства, рабочей силы, товаров и денег), владения и распоряжения ими, как раз и являются прочими производственными отношениями. Если бы они приводились в качестве примеров таковых, то закономерно встал бы вопрос, а чем они отличаются от отношений собственности, которые также, по Марксу, являются отношениями приобретения, владения и распоряже- ния реальными активами предприятия?

Конечно же, регулятор советской политической экономии еще при переходе на марксистско-ленинскую политическую экономию, мог поправить К. Маркса, несмотря на то, что революционные лозунги марксизма были изложены в терминах средств производства. К. Маркс и Ф. Энгельс неоднократно именно поправлялись, а не уточнялись или прояснялись, например, что касается сфер общественного производства, производственные отношения в которых изучает политическая экономия. Как писал К. Маркс в «Капитале» (1867), «предметом моего исследования в настоящей работе является капиталистический способ производства и соответствующие ему отношения производства и обмена» [12, с. XXXII]. В курсе же лекций «Политическая экономия - теоретическая основа революционной борьбы рабочего класса» под ред. Л.И. Абалкина (1983) отмечается: «Специфическим предметом политической экономии являются производственные отношения, т.е. отношения по поводу производства, распределения, обмена и потребления материальных благ в человеческом обществе, образующие экономический строй общества на различных этапах его развития» [13, с. 17]. Таким образом, к производству и обмену как объектам познания науки, по Марксу, добавились обмен и потребление. Почему же очевидная ошибка К. Маркса не была исправлена?

Дело в том, что подмена собственности капиталистов на капитал их собственностью на средства производства была положена в основу выведенного К. Марксом главного противоречия капиталистического общества, которым выступает противоречие между общественным характером производства и частнособственническим характером присвоения, т.е. якобы продукция производится коллективным трудом, но присваивается капиталистом. В действительности произведенная продукция принадлежит не капиталисту, а предприятию, а собственник предприятия, как и наемный работник, не имеет права распорядиться произведенной продукцией по своему усмотрению, например, забрать себе домой часть готовой продукции со склада предприятия, и это всем известно. Но сказать, что капиталисту, как и наемному работнику, произведенная предприятием продукция не принадлежит, что капиталист владеет лишь фиктивными ценностями, а именно капиталом и прибылью, значит отрицать главное противоре- 
чие капитализма. Таким образом, соответствующая поправка К. Маркса фактически означала бы разрушение одного из главных доказательств скорой и неизбежной смены капиталистических производственных отношений социалистическими, на что регулятор марксистско-ленинской политической экономии пойти не мог, так как СССР периодически проводил политику экспорта пролетарской революции, например в 19191937 гг. [14].

В заключение рассмотрим одно роковое последствие отсутствия у К. Маркса экономического взгляда на хозяйственную деятельность. В связи с тем, что К. Маркс смешивал собственность на капитал с собственностью на средства производства, в теории революционной борьбы рабочего класса экспроприация собственников предприятий стала смешиваться с экспроприацией администрации предприятий, прежде всего их высшего руководства, олицетворявшего собственность предприятий на средства производства. Эта коренная ошибка теории революции привела к тому, что администрация предприятий, прежде всего крупных, в период национализации отраслей народного хозяйства в СССР выступила на стороне собственников, поддерживая их политику закрытия предприятий. Так, известно, что на петроградской фабрике «Пекарь» в 1918 г. администрация тормозила работу, подготавливала голодный бунт в подрайоне, неоднократно заявляла о расчете рабочих из-за того, что нет средств им платить [15]. Если бы теория революции отделяла собственников предприятий от администрации предприятий, то последняя, состоящая в большинстве своем из наемных работников, гораздо более позитивно восприняла бы идею социалистической революции, и разруха народного хозяйства, вызванная Первой мировой войной и Октябрьской революцией 1917 года, не была бы столь глубокой и была бы преодолена значительно быстрее.

\section{Библиографический список}

1. Румянцев А. М., Козлов Г.А., Милейковский А.Г. и др. Капиталистический способ производства. Т. 1. // Политическая экономия. Москва. 1977. 608 с.

2. Боровой А. Популярный курс политической экономии. Москва. 1908. 326 с.

3. Туган-Барановский М.И. Основы политической экономии. Санкт-Петербург. 1911. 510 [XI] с.

4. Будович Ю.И. Марксистская трактовка предмета науки как производственных отношений и ее недостатки // Проблемы развития современного общества: экономические, правовые и социальные аспекты. Сб. науч. статей по итогам Всероссийской научно-практической конференции. Под редакцией И.Е. Бельских, А.Ф. Московцева. 2014. С. 57-63.

5. Будович Ю.И. Причины популярности трактовки предмета как производственных отношений в российской политической экономии на рубеже XIX-XX вв. // Экономические науки. 2014. № 117. С. 47-52.

6. Мезенцева В. Почему бухгалтерский учет называют языком бизнеса? [Электронный pecypc] / URL: http://copdoc.ru/articles/673.html.

7. Атлас М. С., Лебедев К.Н. К вопросу о содержании экономических понятий // Вестник Финансовой академии. 2000. № 3. С. 5-15.

8. Лебедев К.Н. Почему модель кругооборота капитала К. Маркса так и не стала теорией бухгалтерского учета // Международный бухгалтерский учет. 2015. № 1 (343). С. 43-52.

9. Ц Цыганков К.Ю. Очерки теории и истории бухгалтерского учета. Москва. 2007. 462 с.

10. Кларк Дж.Б. Распределение богатства. Москва. 2000. 368 с.

11. Большая советская энциклопедия. Экспроприация экспроприаторов [Электронный pecypc] / URL: http://alcala.ru/bse/izbrannoe/slovar-EA/EA10631.shtml

12. Маркс К. Капитал. Критика политической экономии. Т. 1. Книга 1. Процесс производства капитала. МоскваЛенинград. Государственное издательство, 1930. [XLVI] 621 с.

13. Политическая экономия - теоретическая основа революционной борьбы рабочего класса: курс лекций / Под ред. Л.И. Абалкина. Москва. 1983. 512 с.

14. Коммунистический интернационал. Трети и последний / Вопросы CСCP. Ussrvopros. ru URL: http://ussrvopros. ru/politika-sssr/sovetskij-stroj/266-kommunisticheskij-internatsional-tretij-i-poslednij.

15. Рабочий контроль [Электронный ресурс] / URL: https://studfiles.net/preview/4349302/page:31/. 
ЭКОНОМИКА. ЭКОНОМИЧЕСКИЕ НАУКИ

\section{ЭКОНОМИКА И УПРАВЛЕНИЕ НАРОДНЫМ ХОЗЯЙСТВОМ}





\title{
К МОДЕЛИ РАЗВИТИЯ ДАЛЬНЕВОСТОЧНЫХ ТЕРРИТОРИЙ: РЕАЛЬНОСТЬ И ПЕРСПЕКТИВЫ
}

\author{
(c) 2018 Зельднер Алексей Григорьевич \\ доктор экономических наук, профессор, главный научный сотрудник \\ Институт экономики РАН \\ E-mail: tzeldner@gmail.com
}

Приоритетное развитие Дальневосточного федерального округа связано не только с природным потенциалом этого региона, но и с соседством со странами Азиатско-Тихоокеанского региона, обладающими инвестиционным и технологическо-инновационным потенциалом. Одобренная Правительством модель развития Дальнего Востока предполагает привлечение прямых инвестиций, в том числе иностранных. Вариант решения этой задачи в статье предлагается за счет привлечения высокотехнологичных зарубежных технологий на концессионной основе и методов страхования рисков концессионеров. Статья написана при поддержке РФФИ (РГНФ), грант 16-02-00-141.

Ключевые слова: территории опережающего развития, модель развития, технологии, инновации, экономические рычаги, концессии.

Введение: институциональные основы модели развития Дальневосточного федерального округа (ДФО)

Складывающаяся социально-экономическая и политическая обстановка в России вынуждает искать варианты для приоритетного развития регионов, граничащих с высокоразвитыми странами и относительно спокойно воспринимающими низкие темпы экономического роста и введенные против России санкции. Таким регионом на данном этапе развития становится Дальний Восток, ориентированный на страны ATP (Китай, Япония, Южная Корея и другие), которые заинтересованы в потенциальных возможностях ДФО и, как показал начальный период формирования территорий опережающего социально-экономического развития (ТОСЭР), участвующие в качестве инвесторов и резидентов.

Учитывая геополитическое положение ДФО и его потенциальные возможности привлечения зарубежных инвестиций, Дальневосточный регион априори становится зоной приоритетного развития, широко используя новые локализованные формы пространственного развития, такие как ТОСэР, особые экономические зоны, индустриальные парки, что позволит России, при прочих равных условиях, обеспечить технологическое развитие региона.

В октябре 2013 г. Правительство РФ одобрило предложенную Минвостокразвития модель развития Дальнего Востока, основанную на «экспорте в страны Азиатско-Тихоокеанского региона готовых товаров (работ, услуг), создании конкурентоспособного инвестиционного климата, привлечении прямых инвестиций, в том числе иностранных, на росте деловой активности, развитии малого и среднего предпринимательства, создании конкурентоспособных территорий опережающего социально-экономического развития, комплексном развитии Дальнего Востока» [1].

Следует особо отметить, что модель не замыкается только на Дальневосточном федеральном округе. Одним из существенных моментов одобренной правительственной комиссией модели развития Дальнего Востока становится обеспечение международной конкурентоспособности создаваемых форм развития в ДФО в привлечении прямых зарубежных инвестиций.

Для реализации поставленной в модели развития Дальнего Востока цели создана основа институциональной базы, включающая систему законов и нормативных актов Правительства России. Среди них Федеральный закон «О территориях опережающего социально-экономического развития в Российской Федерации» от 29.12.2014 г. № 473-ФЗ. Федеральный закон от 1.05 .2016 г. № 119-Ф3 «Об особенностях предоставления гражданам земельных участков... на территории ДФО...», Закон о свободном порте Владивосток и др. Были сформированы ин- 
ституты развития: Министерство Российской Федерации по развитию Дальнего Востока“; Корпорация развития Дальнего Востока, обеспечивающая строительство инфраструктуры; Агентство развития человеческого капитала и Агентство Дальнего Востока по привлечению инвестиций и поддержке экспорта.

Принятию модели способствовал выход ряда базовых правительственных постановлений и Указов Президента, направленных на отработку отдельных направлений модели пространственного развития Российской Федерации, касающейся и ДФО. Так, в августе 2015 г. выходит постановление Правительства РФ «О содержании, составе, порядке разработки и утверждения стратегии пространственного развития РФ...», в котором рассматриваются приоритетные направления размещения производительных сил на территории РФ. В 2016 г. Минэкономразвития РФ подготовило проект Концепции «Стратегия пространственного развития РФ на период до 2030 г.». В 2017 г. публикуется Указ Президента РФ от 16.01.2017 г. № 13 «Об утверждении основ государственной политики регионального развития РФ на период до 2025 г.» [2], в котором ставятся «приоритетные задачи и механизмы реализации госполитики регионального развития с учетом стратегических национальных интересов». В Указе зафиксирован «дифференцированный подход к реализации мер господдержки регионов и муниципальных образований в зависимости от их социально-экономических и географических особенностей». Одновременно четко обозначена необходимость «снятия инфраструктурных ограничений для опережающего развития территорий с низким уровнем социально-экономического развития... низкой плотностью населения и прогнозируемым наращиванием экономического потенциала» [2]. В общем, эта позиция определяет и отношение к формированию территорий опережающего развития, ДФО как приоритетную пилотную для страны модель с учетом встраивания в международную интеграцию, в первую очередь, со странами АТР, (как звена, способного потянуть за собой технологическое и инновационное развитие страны) в условиях реально происходящей трансформации мировой экономики в соответствии с четвертой промышленной революцией, обеспечивающей развитие всех новейших технологий, меняющих производственные процессы и повышающих конечные результаты.

\section{Инвестиционное обеспечение модели развития ДФО.}

Реализация модели приоритетного развития ДФО предполагает бюджетное обеспечение формирования инфраструктуры, имеется ввиду бюджеты всех уровней и возможности использования современных научных достижений, как отечественных, так и зарубежных. Рассмотрим подробнее состояние этих двух составляющих, обеспечивающих прогрессивное развитие экономики.

О состоянии бюджетного финансирования. В принятом правительством федеральном законе «О территориях опережающего развития в Российской Федерации» № 473-ФЗ от 29.12.2014 г. определено финансирование инфраструктуры за счет бюджетов всех уровней и внебюджетных источников. Еще один источник финансирования - наличие во всех ключевых госпрограммах страны спецразделов по ДФО. Следует отметить, что в условиях усложнения политической и экономической обстановки наблюдается существенная корректировка инвестиционных планов. Так, в соответствии с трехлетним бюджетом на 2018 г. и на плановый период до 2019 г. и 2020 гг. по целевой госпрограмме «Социально-экономическое развитие Дальнего Востока и Байкальского региона» финансирование устойчиво снижается с 33,7 млрд. руб. в 2018 г. до 17,7 млрд. руб. в 2019 г. и 16,9 млрд. руб. в 2020 г. Сложное положение и по другим источникам финансирования ДФО. В утвержденных правительством перечне программ, в которых обязан быть дальневосточный раздел, «предусмотрено только $3,3 \%$ от общего объема финансирования». При этом следует учесть, что это только планы.

К этому следует добавить, что хотя инвестиции в России в текущих ценах в основной капитал в стране растут (с 2013 г. по 2016 г. (включительно) они выросли на 8,8\%), в сопоставимых, начиная с 2013 г. наблюдается снижение в процентах к 1990 г. с 76,2\% в 2013 г. до 66,9\% в 2016 г. [3, c.38]. Снижение объема инвестиций в сопоставимых ценах отразилось и на выполнении феде-

\footnotetext{
" Функции Министерства включают: координацию и реализацию приоритетных проектов; распорядителя бюджетных средств в отношении субсидий на развитие социальной и инженерной инфраструктуры; участие в зонах территориального развития; привлечение инвестиций; управление человеческим капиталом и другие.
} 
ральной адресной инвестиционной программы на 2016 г. Из плановых инвестиционных объектов на 2016 г. в количестве 443 единиц фактически введено на полную мощность 165 объектов [3, с.177], это 37,2\% плана.

В России принята программа «дереструктуризации региональных бюджетных кредитов, общая сумма которых около 0,7 трлн. руб.,, которые должны быть погашены разными долями до 2024 г.» [4]. Рост задолженности регионов системная проблема. Это влияние, как внешних факторов, так и внутренних, обусловленных необходимостью выполнения майских указов президента и медленным ростом доходов большинства регионов. Отсюда необходимость бюджетных и рыночных кредитов и рост задолженности. В то же время с 2015 г. вводятся ограничения на бюджетные кредиты по критерию платежеспособности региона.

Одновременно принимаются меры (Минфином) по сжатию расходной части региональных бюджетов. Ужесточение Минфина по сокращению расходов регионов, включая выдачу бюджетных кредитов, вынуждает регионы активизироваться на коммерческом рынке. Но если бюджетные кредиты и казначейские займы (под 0,1\% на 50 дней) выдавались на льготных условиях, то процентные ставки в коммерческих банках были существенно выше.

С позиции Минфина понятно желание сократить расходы региональных бюджетов, но необходимо помнить о наличии обязательств многих регионов, подтвержденных законодательно, о стимулировании привлечения инвестиций в территории опережающего социально-экономического развития и др., которые предусматривают налоговые льготы для привлечения резидентов.

Сжатие бюджетных расходов регионов, инициированное Минфином, осуществляется параллельно с оптимизацией налоговых распределений «Центр-регионы». Так, «налог на пользователей автомобильных дорог, централизация водного налога, доходов от уплаты акцизов на алкогольную продукцию, уменьшение нормативов по отчислениям в бюджеты регионов по налогу на прибыль организаций, обнуление налога на прибыль организаций и налога на добычу полезных ископаемых для предприятий осуществляющих инвестиционные проекты. Все это приведет к совокупным потерям доходов региональных бюджетов» [5]

В конце 2014 г. принимается ФЗ от 31.12.2014 № 488-Ф3 «О промышленной политике в РФ», в котором целями промышленной политики обозначается «формирование высокотехнологичной конкурентоспособной промышленности, обеспечивающей переход экономики государства от экспортно-сырьевого типа развития к инновационному типу развития». Обоснованное и современное направление развития экономики. Но при этом напряжение с инвестициями из-за низких темпов развития в стране возрастает. И при этом предпринимается попытка переложить часть федеральных финансовых обязательств на региональные и муниципальные бюджеты. Так, в соответствии с ФЗ № 488-Ф3 (ст. 7, п. 1), государственные власти субъектов устанавливают «меры стимулирования деятельности в сфере промышленности за счет средств бюджетов субъекта РФ», а органы местного самоуправления (ст. 8) вправе осуществить меры стимулирования в сфере промышленности на своей территории ... «за счет доходов местных бюджетов ... и поступлений налоговых доходов по дополнительным нормативам отчислений». Эти «меры стимулирования» коснулись, в первую очередь, всех новых форм пространственного развития. Все это происходит на фоне роста совокупного госдолга регионов, которые с 2006 г. вырос до 2,3 трлн. руб. в основном за счет бюджетных и банковских кредитов (Эксперт № 4, 2017 г.).

Как показывает отечественный опыт финансирования инфраструктуры ОЭЗ" и ТОСЭР, федеральный бюджет недовыполняет свои обязательства. В этих условиях возрастает нагрузка на регионы, а в регионах, как мы отметили выше, существенна бюджетная задолженность. Отсюда необходимость бюджетных и рыночных кредитов и рост задолженности. В то же время с 2015 г. вводятся ограничения на бюджетные кредиты по критерию платежеспособности региона.

Как следствие, недофинансирование социальной сферы. Так, по разделу «Здравоохранение» расходы консолидированного бюдже-

\footnotetext{
* Финансирование инфраструктуры ОЭЗ за счет федерального бюджета на 2011-2013 гг. было заложено со снижением объема инвестиций. Так на 2011 г. Управляющей компании ОАО «Особые экономические зоны» выделялось 15,67 млрд. руб., на 2012 г.- 6,03 млрд., и эта же сумма выделялась на 2013 г. (Российская газета. 2010.17.12)
} 
та регионов Дальнего Востока лишь немного превысили половину расходов предыдущего 2016 г. - 57\%. В сумме - это 50 млрд. рублей [6]. При таком подходе к социальной сфере миграция населения ДФО будет продолжаться. В 2017 г. регион покинуло 17 тысяч человек.

Что касается проблемы финансирования территорий опережающего социально-экономического развития (ТОСЭР), то следует отметить, что эффект начальной стадии себя оправдал. Так, в 2017 г. в целом по Дальневосточному федеральному округу прирост инвестиций был в 2,5 раза выше, чем в среднем по России. Но этот прирост в определенной степени был обеспечен строящимися в Амурской области в ТОСЭР «Свободный» газоперерабатывающего завода, инвестиции первого этапа около 1 трлн. рублей. Следует отметить, что в целом по Амурской области объем инвестиций в три ТОСЭР - 1,1 трлн. руб., это 50\% всего объема инвестиций в дальневосточные территории опережающего развития.

Учитывая слабую инфраструктурную обеспеченность ДФО, сложные климатические условия, продолжающийся отток населения, возникают сложности с привлечением частных инвестиций и инвесторов. За последние 4 года реальный удельный вес частных инвестиций составил 3,3\% от общего количества заявленных [6]. Это свидетельствует о том, что без существенного увеличения бюджетных вложений, активного участия крупных холдингов и корпораций, создания условий для использования механизмов ГЧП и, в частности, такой апробированной формы как концессии, развитие ДФО на базе новейших технологий может существенно затянуться.

Эффективное функционирование территорий опережающего развития в условиях ограничения федеральных и региональных инвестиций возможно за счет расширения использования механизмов ГЧП и передачи регионам дополнительных полномочий из тех, которые находятся в совместном ведении с Российской Федерацией. Учитывая достаточно глубокую дифференциацию регионов по их финансовым возможностям, необходимо наделить их дополнительными полномочиями, направленными на пополнение инвестиционных источников. Исходя из главы 3 «Федеративное устройство» Конституции РФ и опираясь на Закон о территориях опережающего развития, целесообразно наделить регионы большими правами в налогообложении, в использовании государственной собственности, природных ресурсов и других льгот и прав, позволяющих обеспечить условия для привлечения как отечественных, так и иностранных инвесторов с целью быстрейшей реализации программы по освоению территорий опережающего развития. С передачей регионам дополнительно части функций, находящихся в совместном ведении, появляется, при прочих равных условиях, возможность налаживания реального воспроизводственного процесса в регионе и улучшение качества управления регионом.

\section{Инновационная составляющая развития} прогрессивных технологий в ТОСЭР

Идущая трансформация мировой экономики в соответствии с четвертой промышленной революцией кардинально меняет все производственные и управленческие процессы, и намечающееся отставание в этой сфере чревато потерями конкурентоспособности российской несырьевой (гражданской) экономики. Это приведет к тому, что Россия прочно утвердится в числе догоняющих стран мира с развитой сырьевой экономикой, тесно зависимой от конъюнктуры мировых цен на сырье и темпов развития альтернативных энергетических источников.

Следует отметить, что складывающаяся ситуация понимается, и формально проводятся определенные действия. Так, в 2017 г. утверждена «дорожная карта» по развитию национальной технологической инициативы «Передовые производственные технологии». Но, как отмечает директор Международного центра программ и проектов в бизнес-образовании РАНХиГС А. Пивоваров, «на практике реальных результатов пока не видно» [7].

Проблема встраивания России в происходящую трансформацию мировой экономики на современном этапе достаточно многоаспектна. Частично она определяется сырьевым лобби, получающим устойчиво сырьевую ренту и очень слабо участвующим в инновационных разработках*. Существенную роль играет и состояние бюджета в условиях политической не-

\footnotetext{
* Удельный вес инновационной активности организаций в сфере добычи топливно-энергетических полезных ископаемых в общем числе обследованных снижается: в 2003 г. он составлял 7,2\%, в 2014 г. - 7,4\%, в 2015 г.6,3\%, в 2016 г. - 5,6\%. (Наука, технологии и инновации в России 2017. М. ИПРАН РАН. 2017. С. 76).
} 
стабильности, учитывающего приоритет национальной безопасности". Немаловажное влияние оказывают и введенные против России санкции, приведшие к разрыву интеграционных связей и необходимости финансировать процесс импортозамещения. Но, при всех прочих условиях, страна должна приоритетно активизировать свою деятельность в направлении ускорения трансформации экономики на новейшей технологической и инновационной основе.
В этом плане необходимо решение первоочередной задачи по обеспечению приоритетного развития гражданской науки в стране, как основы технологического прогресса гражданской экономики и экономической безопасности страны. Для финансирования развития науки, помимо традиционных источников, следует ввести целевой рентный налог на все сырьевые производства, как частные, так и государственные.

\section{Библиографический список}

1. https://minvr.ru/press-center/news/895/

2. http://kremlin.ru/acts/bank/41641

3. Инвестиции в России 2017. Москва. Россстат. 2017.

4. Маврина Л. Оттолкнулись от дна и всплывают // Эксперт № 4. 2017. С. 97

5. Эксперт № 45. 2017. С. 39.

6. https://minvr.ru/press-center/news/13581/

7. Российская газета. Экономика. 24.05.2018. С. 16.

\footnotetext{
" Государственная политика регионального развития реализуется «с учетом стратегических национальных приоритетов РФ...» (Указ Президента РФ «Об утверждении основ государственной политики регионального развития РФ на период до 2025 .» от 16.01.2017 г. № 13, пункт 4), а также факторов и условий неравномерного размещения производительных сил и расселения населения на территории страны и различий в уровне социально-экономического развития регионов.
} 


\title{
СУЩНОСТЬ И ИНСТРУМЕНТЫ АНТИКРИЗИСНОГО МЕНЕДЖМЕНТА
}

\author{
(c) 2018 Захарченко Игорь Сергеевич \\ аспирант \\ Ленинградский государственный университет имени А.С. Пушкина \\ 196605, г. Санкт-Петербург, Пушкин, Петербургское шоссе, 10 \\ E-mail: 193miller@gmail.com
}

В статье рассмотрены существующие подходы по определению сути антикризисного менеджмента предприятия; предложена его трактовка как совокупности управленческий решения и действий, нацеленных на прогнозирование и выявление сигналов возможных угроз, диагностику кризисного состояния предприятия, разработка и внедрение способов предупреждения и подавления негативных последствий. Охарактеризованы инструменты антикризисного менеджмента операционного, тактического и стратегического уровней.

Ключевые слова: предприятие, антикризисный менеджмент, процесс антикризисного менеджмента, инструменты антикризисного менеджента.

Сегодня деятельность любого предприятия зависит от большого количество факторов, которые могут создать кризисную ситуацию и ухудшить показатели его деятельности. Опыт развития экономических систем разного уровня показывает, что кризисное состояние - это один из этапов их функционирования, поэтому понимание процессов, которые происходят как во внутренней, так и во внешней среде экономической системы позволяет заблаговременно выявить угрозу наступления кризиса, предупредить его или разработать и реализовать меры по минимизации возможных негативных последствий. Необходимость мониторинга рисков, предвидения угроз и своевременная реакция обусловили формирование отдельного направления в менеджменте - антикризисного. Именно поэтому вопрос антикризисного менеджмента для отечественных предприятий является актуальным.

Целью исследования является обобщение существующих подходов к определению сущности и инструментов антикризисного менеджмента предприятия. Основными задачами исследования являются: изучение и обобщение существующих подходов к определению сущности антикризисного менеджмента (управления); определение элементов системы антикризисного менеджмента (объекта, субъекта, предмета, цели, принципов, функций, критериев, инструментов), основных этапов его осуществления; характеристика инструментов антикризисного менеджмента операционного, тактического, стратегического уровня.
В исследованиях антикризисное управление и менеджмент рассматриваются с разных позиций и подходов. Так сторонники системного подхода считают, что антикризисное управление деятельностью предприятия должно основываться на теории возникновения и углубления кризиса. Субъект антикризисного менеджмента должен четко понимать свое место и функции в общем механизме функционирования предприятия как системы, обеспечивая своевременное выявление и устранение признаков кризисного состояния.

Так, А. Грязнова, М. Федотова, А. Маринюк определяют антикризисное управление как систему управления предприятием, которая имеет комплексный характер и направлена на избежание или устранение неблагоприятных для бизнеса явлений с помощью использования всего потенциала современного менеджмента, разработки и реализации на предприятии специальной программы, которая имеет стратегический характер и позволяет устранить временные трудности, сохранить и улучшить рыночные позиции предприятия при любых обстоятельствах с использованием преимущественно собственных ресурсов. Антикризисное управление предприятием предусматривает ускоренное и действенное реагирование на существенные изменения внешней и внутренней среды на основе заблаговременно разработанных антикризисных мер [4, с.7].

Ситуационный подход к антикризисному менеджменту сосредотачивает внимание на использовании специальных приемов и методов, 
целесообразных в конкретных обстоятельствах, которые влияют на предприятие в данный период времени. Так, Л. Лигоненко рассматривает антикризисное управление как специальное, постоянно организованное управление, нацеленное на оперативное выявление признаков кризисного состояния и создание соответствующих условий для его своевременного преодоления с целью обеспечения восстановления жизнедеятельности отдельного предприятия, недопустимости возникновения ситуации его банкротства [5, с.37].

Процессный подход антикризисного менеджмента позволяет определить его этапы как процесс и разработать для каждого соответствующие инструменты. А. Градов трактует его как совокупность последовательных обобщенных антикризисных мер, таких как: анализ состояния макро- и микросреды, выбор миссии предприятия; изучение механизма возникновения кризисных ситуаций и создание системы мониторинга внешней и внутренней среды предприятия для раннего выявления слабых сигналов кризиса; стратегический контроллинг деятельности предприятия и разработка стратегии избежания его неплатежеспособности; оперативная оценка и анализ финансового состояния предприятия, выявление вероятности возникновения банкротства; разработка системы действий в условиях кризиса для выхода из кризисной ситуации; постоянный учет риска предпринимательской деятельности и разработка мер для его снижения [2, с.84].

О. Непочатенко трактует антикризисный менеджмент с позиции институционного подхода - как процесса использования форм, методов и процедур, направленных на социально-экономическое оздоровление финансово-хозяйственной деятельности индивидуального предпринимателя, предприятия, отрасли, создание и развитие условия для выхода из кризисного состояния экономики региона или страны в целом [7].

Функциональный подход базируется на уточнении содержательного наполнения традиционных функций менеджмента (планирование, организация, мотивация, контроль) в условиях обострения ситуации и возможности ухудшения результатов деятельности предприятия.

Обобщая можно сказать, что антикризисный менеджмент - это совокупность управленческих решений и действий, нацеленных на прогнозирование и выявление сигналов возможных угроз, диагностику кризисного состояния предприятия, разработку и внедрение мер для предупреждения и снижения негативных последствий. Составляющие антикризисного менеджмента представлены в табл. 1.

Учитывая разнообразие кризисных явлений и наличие разных вариантов их проявления

\section{Таблица 1. Составляющие системы антикризисного менеджмента}

\begin{tabular}{|l|l|}
\hline Объект & $\begin{array}{l}\text { Предвидение и реальные причины кризиса, факторы которые его вызывают, послед- } \\
\text { ствия к которым он приводит }\end{array}$ \\
\hline Субъект & $\begin{array}{l}\text { Лица, которые владеют знаниями, компетенцией и необходимыми ресурсами, осу- } \\
\text { щестляют целенаправленные действия с целью обеспечения устойчивости предприя- } \\
\text { тия к негативным изменениям }\end{array}$ \\
\hline Предмет & $\begin{array}{l}\text { Совокупность взаимоотншений между субъектами антикризисного управления, соз- } \\
\text { данных на предприятия, по отношению к формам, методам и средствам влияния на } \\
\text { объект антикризисного управления }\end{array}$ \\
\hline Цель & $\begin{array}{l}\text { Обеспечение высокого уровня устойчивости, гибкости, адаптивности предприятия для } \\
\text { недопустимости негативных изменений }\end{array}$ \\
\hline Принципы & $\begin{array}{l}\text { Последовательности действий, постоянного присмотра, адаптируемости, динамично- } \\
\text { сти, согласованности действий, оптимальности, временных ограничений, конструктив- } \\
\text { ности, адресности, завершенности }\end{array}$ \\
\hline Функции & $\begin{array}{l}\text { Выявление признаков кризиса, определение степени негативного влияния; разработка } \\
\text { антикризисной программы; организация деятельности; контроль за ее реализацией; } \\
\text { мотивация персонала к активным действиям для преодоления кризиса; корректирую- } \\
\text { щие действия; оценка эффективности антикризисных мер и управленческих решений }\end{array}$ \\
\hline Критерии & $\begin{array}{l}\text { Достижение изменений важнейших показателей, скорость получения положительных } \\
\text { изменений на единицу времени, экономичность получения положительного эффекта, } \\
\text { достаточность изменений для восстановления параметров жизнеспособности пред- } \\
\text { приятия, скорость адаптации социально-экономической системы к изменениям [6] }\end{array}$ \\
\hline Инструменты & $\begin{array}{l}\text { Стратегические. Тактические (организационно-технологические). Операционные (фи- } \\
\text { нансово-экономические) }\end{array}$ \\
\hline
\end{tabular}


и последствий, применяются разные модели, стратегии и инструменты антикризисного менеджмента. Так в источнике [1] описаны модели антикризисного менеджмента по отношению к отдельным параметрам кризиса. По нашему мнению, это скорее поведенческие стратегии, которые используются ситуационно согласно с выделенными параметрами:

- в зависимости от влияния на начало кризисного периода: приближение, которое состоит в создании условий для ускорения кризиса; отдаление как создание условий для отсрочки кризиса; невмешательство как игнорирование ситуации, отсутствие управленческих усилий на начало кризиса;

- в зависимости от влияния на конечный результат: предупреждение возникновения как подготовка и реализация управленческих мер, которые делают невозможным возникновение кризисных явлений; стабилизация положения, когда основное внимание уделяется обеспечению управляемости системы в условиях кризисного состояния; приспособление как минимизация внешних негативных последствий влияния использования возможностей положительных влияний; выход из кризиса как завершение кризисного периода независимо от его последствий, в том числе негативных;

- в зависимости от характера поведения на протяжении кризисного периода: содействие развитию как реализация мер, нацеленных на ускорение противоречий, активизация их проявления; нейтралитет как непринятие управленческих мер, а только накопление ресурсов; борьба с негативными проявлениями и последствиями;

- в зависимости от объекта управленческих усилий: последствия кризиса - антикризисное управление ориентированное на минимизацию негативных последствий кризиса; причины кризиса - управление направленное на локализацию или устранение причин кризиса; продолжительность кризиса - сокращение срока кризиса; комбинированное антикризисное управление;

- в зависимости от привлечения внешних ресурсов и специалистов: внешнее антикризисное управление; внутреннее антикризисное управление; комбинированное антикризисное управление [1].

Разнообразие взглядов о природе возникновения кризисных ситуаций привела к тому, что ученые выделяют разные инструменты антикризисного менеджмента. Они существенно отличаются по направлению действия и силе влияния, группами субъектов менеджмента, которые их используют.

Использование одного или одновременно нескольких инструментов происходит на определённом этапе процесса антикризисного менеджмента, основные из которых: выявление признаков кризиса, определение степени потенциального или реального негативного влияния определённых факторов (угроз) на состояние предприятия; оценка ресурсного потенциала антикризисного менеджмента для проведения антикризисных мер; диагностика кризисных явлений и угрозы банкротства предприятия; определение цели и задачи антикризисного менеджмента; выбор методов, инструментов и приемов антикризисного менеджмента; разработка антикризисных мер или программы; реализация антикризисных мер или программы антикризисного менеджмента, контроль деятельности; корректирующие действия; оценка эффективности антикризисных мер и управленческих решений; разработка профилактических мер, направленных на избежание повторения кризиса.

Так как инструменты операционного уровня применяются в системе менеджмента предприятия традиционно, детальнее рассмотрим инструменты стратегического и тактического уровня. В антикризисном менеджменте особое место занимает маркетинг, так как систематическое сканирование внешней среды предприятия позволяет получать сигналы, которые свидетельствуют о возможной угрозе или появлении дополнительных возможностей для предприятия. В кризисных условиях важно иметь надежных партнеров и поставщиков, поддерживать связи и контакты с потребителями.

Актуализируется антикризисное инновационное управление предприятием, антикризисная кадровая политика. Последняя должна быть реалистичной, творческой, ориентированная на привлечение профессионально подготовленных, с новаторскими задатками людей. При невозможности удержания собственного подразделения, которое занималась бы антикризисным менеджментом, целесообразно использовать консалтинг как получение услуг по рациональному использованию потенциала и ресурсов предприятия для достижения намеченных це- 
лей преодоления кризиса.

Диверсификация является активным методом реагирования на внешние угрозы. Использование стратегии диверсификации позволяет предприятиям создавать принципиально новые товары и услуги на базе использования прогрессивных технологий, развивать новое направление предпринимательства, повышать качественные характеристики продукции, которые изготавливаются, активизировать свою политику на рынке, что в совокупности направлено на оздоровление предприятия, обеспечение его стабильности и развитие.

Реинжиниринг бизнес-процессов в системе антикризисного менеджмента - это совокупность принципов, подходов, процедур и методов, нацеленных на кардинальные стратегические изменения, которые позволяют значительно повысить результативность деятельности предприятия и достичь стратегических целей развития. Использование этого инструмента позволяет выделить и осуществить коренные изменения тех цепочек бизнеса, которые обеспечат прорыв и долгосрочное конкурентное преимущество. Целью реинжиниринга бизнес-процессов является повышение качества системы управления предприятием в ключевых сферах деятельности для формирования конкурентных преимуществ, увеличение уровня конкурентоспособности, экономической эффективности и развития. Основные задачи реинжиниринга бизнес-процессов: смена организационной структуры предприятия с функциональной на кросс-функциональную (бригадная) или горизонтальную на уровне топ-менеджмента и бригадную - на уровне бизнес-процессов; формирование системы мотивации к самостоятельной работе, инициативности в пределах процессов, оценки и награды за полученный результат; формирование новой корпоративной культуры на основе максимального удовлетворения потребностей потребителей.

Антикризисный менеджмент на базе контроллинга в краткосрочном периоде предвидит выживание предприятия, нацеленное на обеспечение прибыльности, а в долгосрочном - на реализацию разработанных стратегических планов в границах допустимых (принятых) отклонений. Средства контроллинга позволяют выявить проблемы, которые возникли в процессе реализации антикризисной стратегии, устранить отклонения путём корректировочных дей- ствий на основе разработанных альтернативных вариантов.

Для консолидации факторов внутренней и внешней среды предприятия эффективным инструментом является интеграция, которая способствует построению законченных технологических цепочек, снижению затрат на одну продукцию, росту продуктивности труда, повышению финансовой стабильности и устойчивости предприятий, снижению уровня неопределенности в поставках и сбыте продукции, снижению рисков. Горизонтальная интеграция обычно осуществляется с целью углубления специализации, увеличения и улучшения качества продукции, повышения эффективности деятельности путем увеличения масштабов, экономии постоянных затрат на единицу продукции, увеличения части рынка и степени экономической концентрации в отрасли. Вертикальная интеграция предусматривает создание специфических межотраслевых производственных связей, которые обеспечивают последовательный технологический процесс от производства сырья до реализации продукции. Использование этого инструмента позволяет удешевить приобретение ресурсов, снизить трансакционные затраты, повысить тем самым финансовую устойчивость и конкурентоспособность предприятия.

В условиях, когда кризис наступил, но предприятие имеет реальную возможность восстановить платежеспособность, ликвидность и прибыльность, принимается решение о проведении санации. Санация может происходить путем: слияния предприятия, которое находится на грани банкротства с более мощным; выпуска новых акций или облигаций для мобилизации финансовых ресурсов; кредитования и субсидии; преобразования краткосрочной задолженности в долгосрочную и так далее. То есть, это комплекс последовательных, взаимосвязанных мер, направленных на выведение субъекта хозяйствования из кризиса, восстановления его прибыльности и конкурентоспособности в долгосрочном периоде.

Реструктуризация предусматривает осуществление организационно-экономических, правовых, технических мер, направленных на изменение структуры предприятия, его управление, формы собственности, организационно-правовые формы, с целью улучшения экономических и финансовых показателей функционирования, привлечение инвестиций; 
усиление конкурентоспособности компании за счёт слияния или поглощения. Единой универсальной модели реструктуризации не существует. Ее содержание определяют размер, структура, технологии, ресурсы, квалификация персонала, уровень менеджмента, текущее состояние предприятия.

Процедура банкротства как метод антикризисного управления предусматривает оздоровление экономики предприятия-должника в условиях потенциальной возможности восстановления платежеспособности путем реализации части его имущества и осуществлении других организационных и экономических мер с целью продолжения его деятельности.

Таким образом, каждый из представленных инструментов используется на определённом этапе разрастания кризиса. Так, контролинг эффективно использовать постоянно, это может быть вмонтированный в систему менеджмента инструмент, но главная его роль как превентивного, вызванного распознать и слабые сигналы с помощью методов диагностики кризисного состояния. Интеграция любого типа предусматривает существенные затраты времени и усилий на поиски партнера для обеспечения реализации интересов предприятий-участников, что не всегда возможно. Диверсификация - достаточно затратная процедура, требующая длительного подготовительного и инвестиционного периода, свободных ресурсов, достаточного потенциала для дальнейших преобразований. Реинжиниринг бизнес-процессов в общем рассматривается как эффективное средство управ- ления, которое дает возможность осуществить “прорыв”, так как дает возможность эффективно управлять бизнес-процессами и предприятием в целом; руководство получает оперативную и достоверную информацию о принятии управленческих решений, возможность контролировать деятельность структурных подразделений, групп бизнес-процессов; меняются функции менеджера с контролирующий на координирующую, основная роль - помощь в решении проблем, которые возникают у них в ходе выполнения бизнес-процесса. Финансовая санация и процедура банкротства инструменты, которые используются в кризисном периоде, когда внутренних ресурсов предприятия недостаточно, но возможности выхода из кризиса ещё есть.

Выводы. Таким образом, стратегические изменения могут быть обусловлены чередой причин, и руководители предприятия должны быть к ним готовы. Эта готовность определяется не только умением распознавать, адаптироваться к влиянием внешней среды, но и выбирать наиболее адекватные инструменты по ситуации. Важно, чтобы было понимание, при каких обстоятельствах усовершенствование существующей системы менеджмента не даст ожидаемых результатов и необходимы кардинальные меры. Указанные стратегические инструменты дают возможность не только не допустить разрастания кризисов, но и возможность получить долгосрочное конкурентное преимущество, восстановить устойчивость предприятия к агрессивным факторам внешней среды.

\section{Библиографический список}

1. Антикризисное управления предприятием: электронный начальный помощник [Электронный ресурс] http://library.if.ua/books/6.html

2. Градов А.И. Стратегия экономического управления предприятием Санкт-Петербург. 1993.375 с.

3. Грибан С.В. Система антикризисного управления предприятием [Электронный ресурс] //Эффективная экономика. 2013. № 11.

4. Грязнова А.Г. Антикризисный менеджмент / А.Г. Грязнова, М.А. Федотова, А.Н. Маринюк и др.; под ред. А.Г. Грязновой. Москва. 1999. 368 с.

5. Лигоненко Л.О. Антикризисное управление предприятием: монография. Киев. 2001.580 с.

6. Маховка В.М. Методология формирования системы антикризисного управления предприятия [Электронный ресурс] // Инновационная экономика. 2013. № 39. С. 105.

7. Непочатенков О.О. Финансовый менеджмент / О.О. Непочатенков, Б. С. Гузар. Киев. 2013. 496 с.

8. Рязанова О. Е., Левченко Л.В. Инвестиционный климат как условие для развития инновационной экономики // Экономические науки. 2014. № 114. С. 14-28.

9. Урумова Ф.М. Классификация общественных институтов и эффективность их реализации // Экономический журнал. 2005. № 1 (9). С. 75-92. 
ЭКОНОМИКА. ЭКОНОМИЧЕСКИЕ НАУКИ

\section{ФИНАНСЫ, ДЕНЕЖНОЕ ОБРАЩЕНИЕ И КРЕДИТ}





\title{
ФУНКЦИОНАЛЬНОЕ ЗНАЧЕНИЕ ФОНДОВОГО РЫНКА ДЛЯ РАЗВИТИЯ ЭКОНОМИКИ РЕСПУБЛИКИ БЕЛАРУСЬ
}

\author{
(c) 2018 Ливенский Валентин Михайлович \\ кандидат географических наук, доцент кафедры финансов \\ Полесский государственный университет \\ 225710, Республика Беларусь, г. Пинск, ул. Днепровской флотилии, д. 23 \\ E-mail: livey@tut.by
}

В статье проведён качественный и количественный анализ деятельности фондового рынка Республики Беларусь; в рамках исследования выявлены проблемы его функционирования и предпринята попытка найти пути их решения.

Ключевые слова: национальная экономика, фондовый рынок, рынок акций, рынок облигаций.

В условиях современной мировой экономики во всех развитых и развивающихся государствах наличие развитого и функционирующего фондового рынка имеет для развития национальной экономики огромное значение. Фондовый рынок является составной частью финансового рынка и играет первостепенную роль в экономике страны, т.к. именно через фондовый рынок происходит перераспределение финансовых ресурсов между отраслями и сферами экономики, стимулирование инвестиций и их трансформация из непроизводительной в производительную форму, а также финансирование бюджетного дефицита. Основным преимуществом использования фондового рынка в качестве инструмента финансирования экономики является возможность принятия более взвешенных инвестиционных решений на основании рыночных цен с учётом реального положения всех участников рынка, тем самым повышая эффективность финансовой системы страны в целом [1]. В Республике Беларусь (РБ) в последнее время также большое внимание уделяется практической значимости развитию фондового рынка, что, в конечном счёте, предполагает выход национальной экономики РБ на совершенно новый уровень своего развития. В этой связи все заинтересованные лица на всех уровнях постоянно совершенствуют законодательство РБ по либерализации условий осуществления деятельности на фондовом рынке РБ, сближения законодательства и отчётности РБ с международными стандартами, создания условий для размещения ценных бумаг эмитентов из РБ на зарубежных фондовых площадках [2].

Здесь необходимо отметить, что на фондовом рынке РБ преобладающее значение имеют банки РБ, которые могут выступать как эмитентами, так и инвесторами или фондовыми посредниками. На рисунке 1 показана динамика объёмов торгов банками РБ на рынке акций за последние 4 года.

Как видим, активность банков РБ на рынке акций постоянно растёт. За 2017 г. объём торгов увеличился по сравнению с 2016 г. в 2,6 раз. Все операции были осуществлены посредством непрерывного двойного аукциона. Самыми активными банками были: ОАО «Белинвестбанк» (объём торгов - 391,15 млн. руб.), ОАО «АСБ Беларусбанк» (объём торгов - 50,66 млн. руб.), «Приорбанк» ОАО (объём торгов - 19,60 млн. руб.).

Так же отметим, что по состоянию на 01.01.2017 г. к обращению на бирже РБ допущены были акции 2358 предприятий юридических лиц. Из них акции 1 юридического лица (2 выпуска) - включены в котировальный лист «А» первого уровня, акции 18 юридических лиц включены в котировальный лист «А» второго уровня, акции 48 юридических лиц включены в котировальный лист «Б», в качестве внесписочных ценных бумаг к обращению допущены акции 2291 юридического лица. Эти данные отображены в табл. 1.

В разрезе видов ценных бумаг объём сделок с акциями в 2014 г. уменьшился на 15\%. При этом следует отметить существенное снижение размещения акций на первичном рынке. Данную тенденцию можно проследить на рисунке 2.

Суммарный объём вторичных торгов акциями за 2014 г. составил 479,2 млрд. руб. (уменьшение по сравнению с 2013 г. в 1,1 раза) или 37950012 акции (за 2013 г. объём составил 510,3 млрд. руб. или 141795577 акций). Количество 


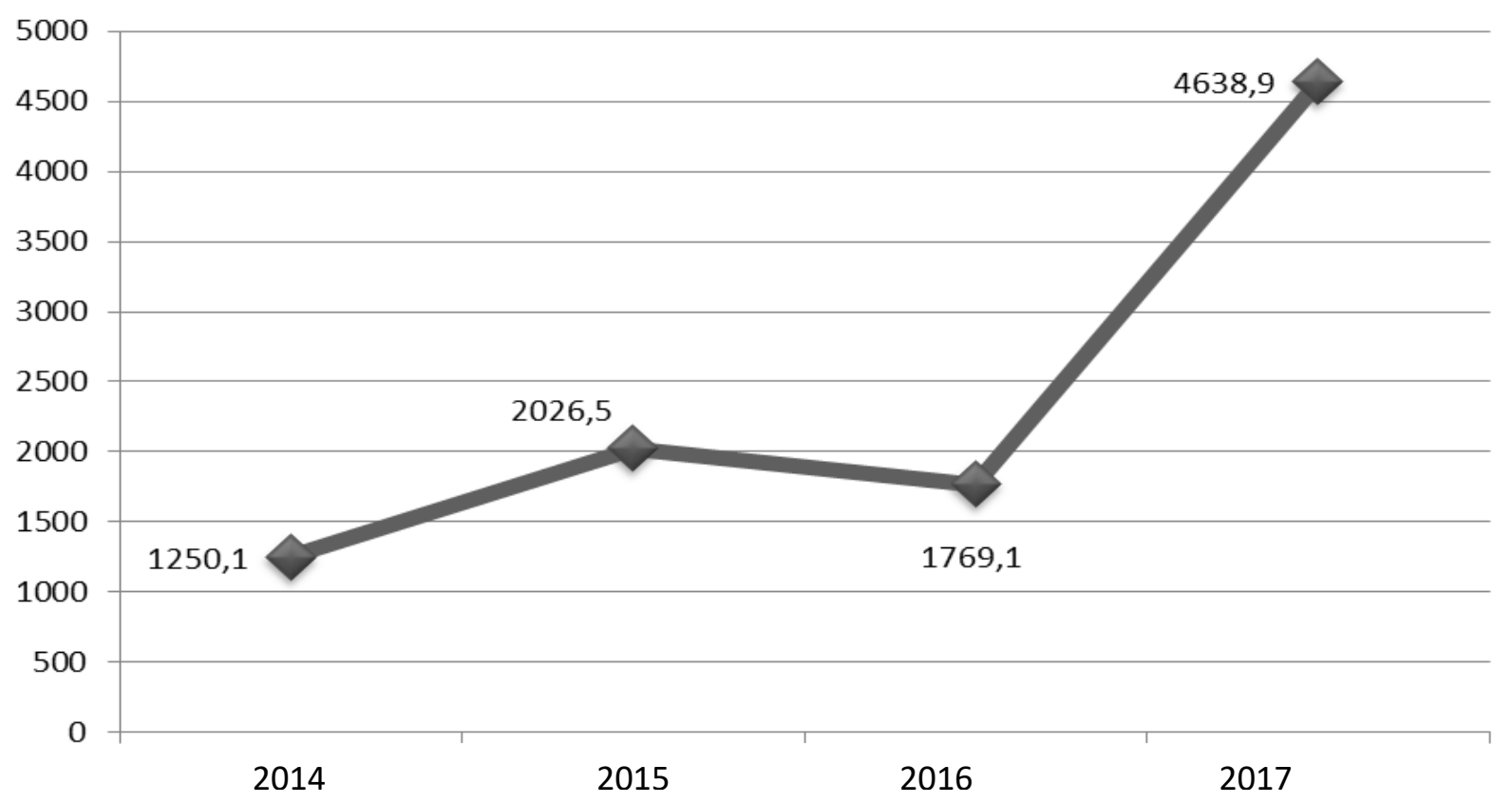

Puc. 1. Динамика объемов сделок банками РБ на рынке акций за 2014-2017 гг. Источник. Собственная разработка на основе [3]

Таблица 1. Котировальные списки по числу эмитентов РБ

\begin{tabular}{|c|c|c|c|c|c|}
\hline \multirow{2}{*}{ Вид ценой бумаги } & \multicolumn{3}{|c|}{ Котировальный лист } & \multirow{2}{*}{ Вне списка } & \multirow{2}{*}{ Всего } \\
\hline & Al & All & Б & & \\
\hline Акции & 1 & 18 & 48 & 2291 & 2358 \\
\hline Облигации субъектов хозяйствования & 9 & - & 5 & 52 & 66 \\
\hline Облигации местных займов & - & - & - & 17 & 17 \\
\hline
\end{tabular}

Источник [3]

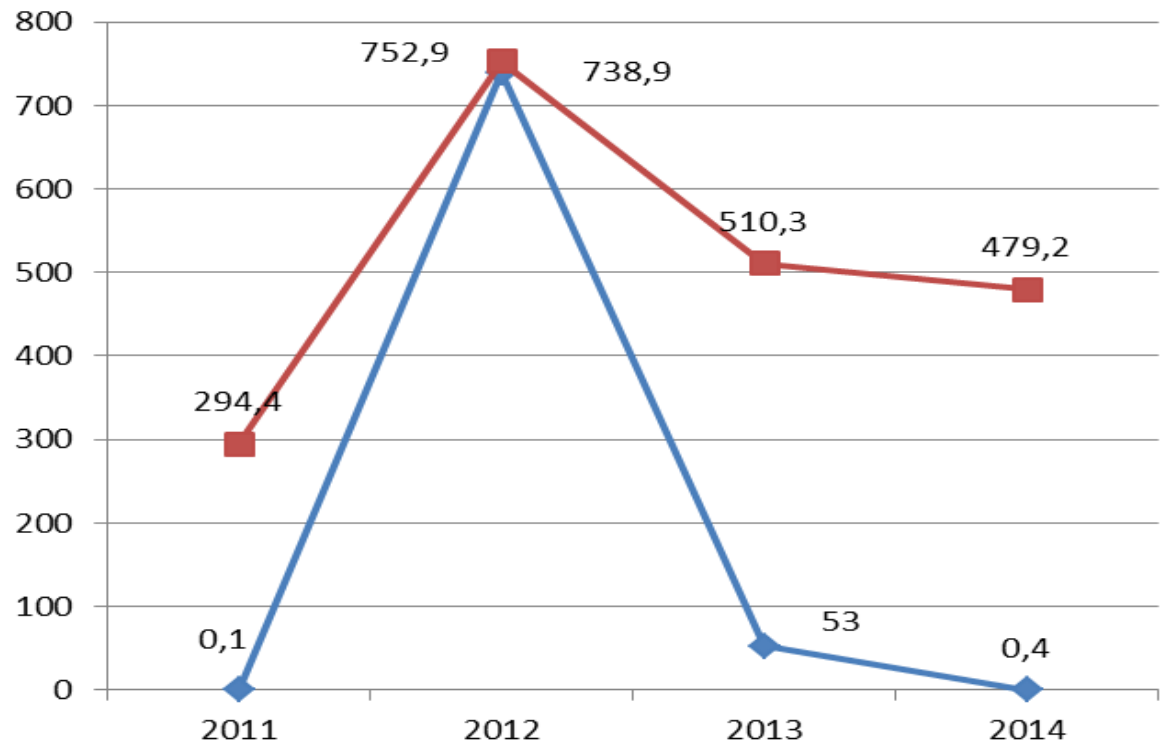

— Первычный рынок - - Вторичный рынок

Puc. 2. Динамика объемов сделок с акциями на первичном и вторичном рынках, млрд. pyб. (BYR) Источник. Собственная разработка на основе [3] 
сделок, заключённых с акциями в биржевой торговой системе в 2014 г., равно 5815 (за 2013 г. 6959 сделок). Количество эмитентов РБ, с акциями которых в отчётном периоде совершались сделки в общей сложности составило 263.

Бум роста объёма сделок с акциями связан с организацией и проведением IPO белорусских предприятий. В течение 2012 г. на биржевой площадке РБ было проведено публичное размещение акций следующих белорусских эмитентов: ОАО «Минский завод игристых вин», ОАО «Амкодор - Дзержинск», ОАО «Амкодор - управляющая холдинговая компания» и ОАО «Амкодор Унимод».

Что касается облигаций, то по состоянию на 01.01.2017 г. к обращению на секции «Фондовый рынок» были допущены облигации 66 эмитентов. Из них облигации 9 эмитентов - включены в котировальный лист «А» первого уровня, в котировальный лист «Б» включены 5 эмитентов, в качестве внесписочных ценных бумаг к обращению на бирже были допущены облигации 52 эмитентов.

За 2017 г. всего зарегистрировано было 456 выпусков корпоративных облигаций и облигаций местных займов, 211 эмитентов на сумму эмиссии 5572,31 млн. руб., в том числе:

- объём эмиссии облигаций банков РБ составил 3402,46 млн. руб. или $61,1 \%$ от общего объёма эмиссии;

Объём эмиссии зарегистрированных выпусков увеличился по сравнению с 2016 г. в 2,1 раза (за 2013 г. объём эмиссии составил 2675,01 млн. руб.), в том числе:

- облигаций банков - увеличение в 2,4 раза (за 2016 г. объём эмиссии и составил 1446,75 млн. руб.)

Информация о зарегистрированных в 2016 г. выпусках облигаций в разрезе эмитентов представлена в табл. 2.
Как видно из таблицы 2 , из 33 существующих банков РБ, 21 банк выпустил 120 выпусков облигаций в размере 3402,46 млн. руб. Данные выпуски составляют $61,1 \%$ от общего объёма эмиссии, что характеризует банки РБ как активных участников секции «Фондовый рынок».

В общем списке эмитентов РБ по состоянию на 01.01.2016 г. объём зарегистрированных и принятых к обращению облигаций банков РБ по сравнению с 01.01.2015 г. увеличился на 1,6\% и составил 5992,64 млн. руб.

Отметим, что Указом Президента РБ от 28 августа 2006 г. № 537 «О выпуске банками облигаций» банкам РБ представляется возможность выпускать свои облигации, обеспеченные всеми обязательствами по возврату основной суммы долга и уплате\% по предоставленным ими кредитам на строительство, реконструкцию или приобретение жилья под залог недвижимости. В 2014 г. объём эмиссии таких ипотечных облигаций составил 10,00 млн. руб. (BYN).

Общий объём эмиссии ипотечных облигаций, находящихся в обращении по состоянию на 01.01.2015 г. составил 14,68 млн. руб. (1 выпуск ипотечных облигаций ОАО «АСБ Беларусбанк» и 1 выпуск ипотечных облигаций ОАО «Белинвестбнк»).

Как видно, банки РБ очень тесно сотрудничает с Белорусской валютно-фондовой биржей, т.к. они являются основными её участниками.

Далее проанализируем, насколько на практике в РБ выполняются ключевые факторы (условия) для эффективной деятельности всех заинтересованных участников фондового рынка, а именно:

- свобода перемещения капитала;

- ликвидность ценных бумаг;

- инфраструктура фондового рынка РБ;

- финансовая культура и информационная прозрачность фондового рынка;

Таблица 2. Зарегистрированные выпуски облигаций в разрезе эмитентов за 2016 г.

\begin{tabular}{|l|c|c|c|c|c|c|}
\hline \multirow{2}{*}{\multicolumn{1}{|c|}{ Тип эмитента }} & \multicolumn{2}{|c|}{ Количество эмитентов } & Количество выпусков & \multicolumn{2}{|c|}{ Объем эмиссии } \\
\cline { 2 - 7 } & штук & $\begin{array}{c}\text { \% от общего } \\
\text { количества }\end{array}$ & штук & $\begin{array}{c}\text { \% от общего } \\
\text { количества }\end{array}$ & $\begin{array}{c}\text { Млн. руб. } \\
\text { (ВҮN) }\end{array}$ & $\begin{array}{c}\text { о от общего } \\
\text { объема } \\
\text { эмиссии }\end{array}$ \\
\hline Банки & 21 & 10,0 & 120 & 26,3 & 3402,46 & 61,1 \\
\hline $\begin{array}{l}\text { Небанковские организа- } \\
\text { ции }\end{array}$ & 154 & 73,0 & 272 & 59,6 & 1884,84 & 33,8 \\
\hline $\begin{array}{l}\text { Местные исполнительные } \\
\text { и распорядит. органы }\end{array}$ & 36 & 17,0 & 64 & 14,1 & 285,01 & 5,1 \\
\hline Итого: & 211 & 100 & 456 & 100 & 5572,31 & 100 \\
\hline
\end{tabular}

Источник. Собственная разработка на основе [3] 
- законодательная база;

- повышение финансовой грамотности и инвестиционной культуры населения на рынке ценных бумаг в РБ.

Свобода перемещения капитала в РБ. Следует отметить, что в настоящее время существуют некоторые препятствия по обращению акций и облигаций на фондовом рынке в РБ. Это, прежде всего, связано с нахождением значительной доли акций ведущих предприятий РБ в государственной собственности. Так, например, на 01.01.2018 г. государству принадлежало 83,6\% акций акционерных обществ РБ, что составляет 75,5\% от общего объёма их эмиссии. И пока государство крайне не заинтересовано в продаже частным инвесторам акций высокорентабельных белорусских предприятий. Более того, до сих пор существует список стратегических белорусских предприятий, акции которых продавать запрещено законодательно. Из этого следует, что широкое обращение акций на фондовом рынке РБ сведено к минимуму. Таким образом, при существующем достаточно жёстком контроле со стороны государства над фондовым рынком РБ о приемлемой свободе перемещения капитала говорить пока не приходиться [4].

Что касается физических лиц, то единственная возможность стать акционером появляется у них лишь тогда, когда они становятся работниками какого-нибудь белорусского предприятия, планирующего эмиссию акций, купив при этом небольшой «пакет» акций в надежде получать дивиденды. Это практика, которую прошли акционеры многих государственных белорусских предприятий. Акции успешных предприятий приобрести практически невозможно. Поэтому, единственным и возможным на сегодня видом ценных бумаг, по которым физические лица РБ могут заработать, является облигации. Однако данные облигации являются банковскими и приобретаются они на внебиржевом рынке.

К проблемам развития рынка акций можно отнести и ряд других факторов, например: недостаточная приватизация многих государственных белорусских предприятий, а это не позволяет использовать возможный потенциал рынка акций РБ для трансформации сбережений граждан республики в инвестиции, а также служит препятствием для привлечения в экономику РБ иностранных инвестиций; также низкий уровень прозрачности рынка акций, т.е. незаинтересованности белорусских эмитентов в раскрытии информации о результатах своей финансово-хозяйственной деятельности в соответствии с международными стандартами.

Ликвидность ценных бумаг в РБ. Отметим, что и уровень ликвидности рынка корпоративных ценных бумаг в РБ остаётся низким, что связано с небольшим объёмом предложенных для обращения на фондовый рынок ценных бумаг (главным образом акций). Так, например, в общем объёме сделок на вторичном рынке и в разрезе всех ценных бумаг доля акций составляет $1,9 \%$.

В связи с отсутствием котировок осуществлять спекуляции на фондовом рынке РБ, как это принято делать за рубежом, по-прежнему невозможно. Но покупать акции можно либо у физических лиц, ставших акционерами в процессе приватизации, либо при размещении новых эмиссий акций уже существующими ОАО. Но делать это, как правило, имеет смысл тогда, когда инвестор заинтересован не столько в получении дохода от самих акций, сколько в участии в управлении обществом. Надежды на широкое распространение практики размещения акций белорусских ОАО посредством IPO на белорусском рынке пока не оправдались.

Такая же низкая ликвидность и у корпоративных облигаций. Зачастую корпоративные облигации используются как замена банковскому кредиту, когда по каким-либо причинам банк не хочет выдавать предприятию кредит, но готов организовать выпуск облигаций и полностью выкупить их. Такие ценные бумаги до погашения находятся у банка, и ни на какой рынок не попадают, и соответственно их ликвидность не растёт. Такая стратегия во многом оправдана: в РБ пока мало представлены институты, которые традиционно вкладывают деньги в корпоративные облигации.

Существенная часть облигаций субъектов хозяйствования РБ номинирована в иностранной валюте, что обусловлено высокой волатильностью, а также значительной разницей процентных ставок по валютным и рублевым инструментам на финансовом рынке РБ. Отмеченная тенденция ведёт к росту валютных рисков как эмитентов, так и инвесторов, что может негативно отразиться на их финансовом состоянии.

Инфраструктура фондового рынка РБ. В настоящее время вся действующая инфраструктура фондового рынка РБ состоит из: ОАО «Белорусская валютно-фондовая биржа» (торговая 
система), централизованной двухуровневой депозитарной системы РБ и профессиональных участников рынка.

Из этого следует, что проведение всех сделок с акциями белорусских эмитентов возможно исключительно через торговую систему Белорусской валютно-фондовой биржи с привлечением профессиональных участников (далее - профучастники) - членов соответствующей фондовой секции. В тоже время, сделки купли-продажи с акциями белорусских эмитентов между профучастниками фондового рынка в РБ, осуществляемые через Белорусскую валютно-фондовую биржу, иногда связаны с дополнительными издержками, которые для миноритарных акционеров зачастую превышают выгоду от проведения сделки купли-продажи.

В тоже время, в соответствии с п. 65 Инструкции о некоторых вопросах вы-пуска и регистрации ценных бумаг в РБ, утверждённой постановлением Министерства финансов РБ от 11 декабря 2009 года № 146, решение о выпуске облигаций разрабатывается с широким участием профессиональных участников фондового рынка РБ [5]. И если размещение осуществляется на Белорусской валютно-фондовой бирже, то продажа облигаций может осуществляться только профессиональными участниками.

Финансовая культура и информационная прозрачность фондового рынка РБ. Здесь нужно отметить, что на сегодня на рынке ценных бумаг ещё нередко имеет место недобросовестная практика, связанная с манипулированием фондовым рынком РБ, в т.ч. неисполнением некоторых своих обязательств. Кроме этого, некоторые физические и юридические лица привлекаются иногда к административной ответственности за нарушения на рынке ценных бумаг, за нарушения порядка учёта сделок с ценными бумагами, а также незаконное разглашение информации о результатах финансово-хозяйственной деятельности белорусских эмитентов.

Для повышения прозрачности рынка ценных бумаг в РБ, согласно Закону «О рынке ценных бумаг» и в целях организации информационного обеспечения всех участников рынка ценных бумаг и государственных органов установлена обязанность регулятора рынка обеспечивать всех профучастников единым информационным ресурсом о рынке ценных бумаг в РБ.
Законодательная база фондового рынка РБ. Главным нормативным документом, регулирующим развитие фондового рынка РБ на долгосрочную перспективу, в настоящее время является «Программа развития рынка ценных бумаг РБ на 2015-2019 гг.». В данной программе широко предусмотрены основные мероприятия, ориентированные на создание необходимых предпосылок и условий привлечения инвестиций в экономику РБ посредством эмиссии акций и облигаций белорусских эмитентов. Ко всему прочему, среди принятых мер присутствуют мероприятия по совершенствованию системы государственного регулирования рынка ценных бумаг в РБ, развитие и совершенствование биржевой и депозитарной систем, налогового законодательства в части налогообложения доходов от операций с ценными бумагами и т.д.

Повышение финансовой грамотности и инвестиционной культуры населения В РБ. Сегодня Департамент по ценным бумагам на Интернет-странице Министерства Финансов РБ обеспечил широкое информационное поле для граждан, где подробно сказано о состоянии, правовых основах, тенденциях и перспективах долгосрочного развития фондового рынка РБ. Руководство и сотрудники Департамента так же часто организуют тематические семинары по конкретным вопросам, относящимся к компетенции Департамента, а также размещают публикации соответствующего законодательства о ценных бумагах РБ в периодической печати (журнал «Юрист»).

Отметим также, что мировой опыт свидетельствует о том, что срочный рынок занимает большую долю любой национальной экономики, и его ёмкость всегда прямо пропорциональна соответствующему уровню развития рыночных отношений в рамках экономики любого государства, её устойчивости. В развитых странах объём срочного рынка превосходит размер ВВП. В странах с развивающимися финансовыми рынками, в число которых можно отнести и РБ, срочные биржи и секции срочной торговли на биржах могут являться важнейшим стабилизатором как для национального финансового рынка, так и для национальной экономики в целом.

Система биржевого срочного валютного рынка РБ сходна с российской системой и строилась на основе опыта и учёта ошибок последней. Среди основных различий можно выделить следующие: 
- российский рынок работает на протяже- лись. нии последнего десятилетия, в РБ его пока нет;

- в России существует проблема регулирования срочного рынка: кто и за что отвечает в органах государственного управления, в РБ все вопросы регулирования определены в Правилах организации срочных сделок;

- Россия учится на своём опыте, а Беларусь на опыте России.

Фьючерсный рынок в РБ представлен только фьючерсными контрактами на доллары США, ЕВРО и российские рубли. В основе популярности таких операций с валютными фьючерсами лежат серьёзные колебания на мировых валютных площадках, что позволяет их участникам получать приличные доходы на курсовых разницах. На этом список ценных бумаг, допущенных и обращающихся на белорусском рынке ценных бумаг, заканчивается. А такие ценные бумаги, как векселя, опционы и др. на биржевом рынке с 1 квартала 2015 г. в обороте вообще не значи-

Таким образом, можно сформулировать следующие проблемы функционирования рынка ценных бумаг в РБ:

- жёсткий контроль со сторон государства не позволяет достаточно свободно перемещаться капиталу;

- тяжёлый доступ физических лиц к инструментам рынка ценных бумаг;

- низкий уровень объёмов торгов на вторичном рынке акций;

- низкая ликвидность корпоративных облигаций;

- сложный выход небольших компаний на рынок ценных бумаг;

- дублирование законодательства;

- неразвитость срочного рынка.

И как нам представляется, определив круг проблем развития рынка ценных бумаг в РБ, в дальнейшем профессионалы должны начать поиск основных направлений для их решения.

\section{Библиографический список}

1. Белоглазова Г. Н., Киевич А.В. Модернизация регулирования финансовых систем: поиск новых моделей // Банковское дело. 2011. № 7. С. 14-20.

2. Киевич А. В., Бухтик М.И., Койпаш Д. А. Роль доходов населения в финансировании реальных инвестиций в Республике Беларусь // Экономические науки. 2017. № 148. С. 83-88.

3. Отчёт о деятельности в 2017 году ОАО «Белорусская валютно-фондовая биржа» [Электронный ресурс].- Режим доступа: http://www.bcse.by/ru/about/index/49. - Дата доступа: 03.05.2018 г.

4. Киевич Д. А., Койпаш И.Ю. Инвестиционная деятельность в Республике Беларусь: проблемы и пути её совершенствования // Современные аспекты экономики.- 2017 . № 5 (237). С. 5-8.

5. Инструкции о некоторых вопросах выпуска и регистрации ценных бумаг: утв. Министерством Финансов 11.12.2009 г. № 146 (с изм. и доп. по состоянию на 30.06.2012 г.) // Консультант Плюс: Беларусь [Электронный ресурс].- Дата доступа: 19.05.2018 г. 


\title{
ФИНАНСОВЫЙ МЕХАНИЗМ МЕДИЦИНСКИХ ОРГАНИЗАЦИЙ В РФ
}

\author{
(c) 2018 Валиева Елизавета Николаевна \\ доктор экономических наук, профессор \\ Самарский государственный экономический университет \\ 443090, г. Самара, ул. Советской Армии, д. 141 \\ E-mail: rad8063@yandex.ru \\ (c) 2018 Курнакина Наталья Владимировна \\ кандидат экономических наук, заместитель главного врача по экономическим вопросам \\ Самарская стоматологическая поликлиника № 2 \\ 443009, г. Самара, ул. Свободы, д. 121 \\ E-mail: nv125@rambler.ru
}

Статья посвящена вопросам финансового управления в медицинских организациях. Представлен состав их финансового механизма. Дана характеристика его блоков и инструментов. Сформулированы предложения, направленные на развитие методов финансового менеджмента в здравоохранении.

Ключевые слова: медицинские организации, финансовый механизм в медицине.

В современных условиях финансовые отношения в экономике и социальной сфере формируются не произвольно - по мановению «невидимой руки» рынка А. Смита, а являются результатом регулирования для достижения стратегических и тактических целей государственной или корпоративной финансовой политики. Несмотря на реализацию ряда государственных программ, задача совершенствования организации и финансирования здравоохранения продолжает оставаться актуальной [4]. Организационно-экономические мероприятия и способы регулирования в области формирования и использования финансовых ресурсов в здравоохранении, разрабатываемые органами управления, образуют его финансовый механизм В широком смысле финансовый механизм - совокупность видов, форм организации финансовых отношений, специфических методов формирования и использования финансовых ресурсов и способов их количественного определения [6]. Конечными получателями финансовых ресурсов в здравоохранении являются медицинские организации. Наличие различных источников финансирования их деятельности предполагает использование системы инструментов и рычагов управления денежными потоками. «Каждому источнику финансирования соответствует специфический механизм использования: от предельной регламентации для бюджетного финансирования до самостоятель- ного распоряжения средствами, полученными от оказания платных медицинских услуг. В итоге, в составе медицинского учреждения оказывается нескольких субъектов хозяйствования с разными целями, механизмами финансирования и использования средств, полученных от их финансирования»,- считает Т.А. Бородина, рассматривая механизм согласования экономических интересов в здравоохранении [3].

На современном этапе финансовое планирование для медицинской организации заключается в формировании Плана финансово-хозяйственной деятельности. В основу положен принцип использования кадровых ресурсов и нормативной нагрузки. Медицинская организация определяет профиль врачей-специалистов, устанавливает нормативную нагрузку (функцию врачебной должности - количество услуг в год на 1 ставку врача). В результате суммирования получается объем услуг, который может оказать медицинская организация. Однако прикрепленное по системе ОМС население может нуждаться в медицинской помощи по такому профилю, специалист по которому в данном лечебно-профилактическом учреждении (ЛПУ) отсутствует. В этом случае медицинская организация направляет прикрепленного к ней застрахованного пациента в другое лечебно-профилактическое учреждение. В свою очередь, неприкрепленные к данной медицинской организации застрахованные лица могут получать услуги по направ- 
лениям из других ЛПУ. Такой же принцип используется при планировании стационарной и стационарозамещающей помощи. Как правило, практикуется процедура обоснования организацией плановых объемов медицинской помощи на следующий год в разрезе ее видов и профилей. Однако, ценовые и финансовые показатели рассчитываются только на уровне Комиссии по разработке программы. Для реализации возможности планирования медицинских услуг на уровне организации не предусмотрено единых методик. Планирование стоимостных составляющих на уровне медицинской организации может быть использовано только для оперативного расчета на период утверждения плановых объемов. Ценовые категории на год утверждаются Тарифным соглашением в прейскурантах на услуги по ОМС. Совокупная плановая сумма финансирования услуг определяется в плановом объеме, утвержденном Комиссией.

Качество составления предложений медицинской организации по оказанию услуг и его финансовому обеспечению играет очень важную роль. Сопоставление предложений медицинской организации с планом, утвержденным Комиссией по разработке программы [2], свидетельствует о том, насколько учреждение владеет ситуацией и способно ею управлять.

Планирование оказания платных услуг - самое слабое звено в управленческой деятельности медицинской организации. Оно сводится к составлению плана доходов и расходов при составлении Плана финансово-хозяйственной деятельности. Регламента для проведения таких мероприятий на уровне медицинских учреждений не существует. Фактически доходы от оказания платных услуг призваны «латать дыры» в финансовом обеспечении медицинской организации, вызванные ее хроническим недофинансированием из бюджетных средств и средств обязательного медицинского страхования. К этому выводу в своих работах приходят Ф.Н. Кадыров [5], С.М. Сюркова [6]. При внедрении научно-обоснованных методик планирования оказания платных услуг и их структуры, при грамотной тарифной политике медицинская организации имеет возможность значительно повысить эффективность своей финансовой деятельности.

В настоящее время финансирование расходов на оказание медицинской помощи в рамках государственного задания осуществляется без увязки с выполнением количественных показателей. Плановое задание содержит данные по количеству оказанных услуг. Затем определяется предельная сумма финансирования. Медицинская организация может превысить или не исполнить плановый показатель по объему предоставленной помощи, финансирование от этого не изменится. Установленный порядок мониторинга выполнения плановых объемов на ведомственном уровне [1] не используется лечебным учреждением для управления объемами помощи. Данный подход - остаточное явление сметного финансирования. Как таковая стоимость услуги и ее оплата по мере выполнения не предусмотрены. Нормативные затраты на единицу услуги служат для определения совокупного объема финансирования на год. При осуществлении расходов менеджмент ориентируется не на объемы оказанных услуг, а на план финансирования по кварталам внутри года.

В процессе финансово-хозяйственной деятельности создаются финансовые и денежные потоки, обеспечивающие формирование и получение доходов, осуществление расходов. Соответственно, финансовое управление медицинской организацией должно быть направлено как на регулирование процессов получения доходов (грамотное планирование, мониторинг выполнения планов, анализ, принятие управленческих решений), так и на контроль за расходованием финансовых средств. Контролируя соответствие фактических значений показателей плановым параметрам, медицинская организация способна управлять формированием доходной части своего ПФХД. Однако в целях финансового управления следует учитывать различия в периодах формирования фактических и кассовых доходов (табл. 1).

При планировании расходной части медицинская организация должна руководствоваться: объемом финансирования по каждому источнику, соответствием плана расходов и их структуры по определенному виду помощи нормативным показателям, обязательностью соблюдения натуральных норм расходов по определенным статьям, сроками осуществления кассовых расходов.

Для увязки оплаты расходных обязательств с финансовой возможностью организации в данном периоде, необходимо к каждой группе платежей применять определенные методы управления, которые изложены в табл. 2. Этот процесс 
Таблица 1. Сроки формирования фактических и кассовых доходов с учетом видов медицинской помощи и источников ее финансирования

\begin{tabular}{|c|c|c|}
\hline \multirow{2}{*}{ Вид помощи } & \multicolumn{2}{|c|}{ Сроки формирования доходов } \\
\hline & фактических & кассовых \\
\hline $\begin{array}{l}\text { Медицинские услуги в рамках ТП } \\
\text { ГГ за счет средств ОМС }\end{array}$ & $\begin{array}{l}\text { Выставление счетов за оказанные } \\
\text { услуги (1 раз в } 10 \text { дн) }\end{array}$ & $\begin{array}{l}\text { Авансовые платежи за текущий } \\
\text { месяц (40\% от среднемесячной } \\
\text { суммы) - с } 12 \text { по } 28 \text { число; расчет } \\
\text { за предыдущий месяц - с } 10 \text { по } 18 \\
\text { число }\end{array}$ \\
\hline $\begin{array}{l}\text { Медицинские услуги в рамках } \\
\text { выполнения государственного } \\
\text { задания за счет средств областного } \\
\text { бюджета }\end{array}$ & По итогам месяца & - \\
\hline $\begin{array}{l}\text { Оказание платных медицинских } \\
\text { услуг населению }\end{array}$ & $\begin{array}{l}\text { Выставление счетов за оказанные } \\
\text { услуги (ежедневно) }\end{array}$ & $\begin{array}{l}\text { Ежедневно или по мере заверше- } \\
\text { ния услуги }\end{array}$ \\
\hline $\begin{array}{l}\text { Оказание платных медицинских } \\
\text { услуг по договорам ДМС и с юри- } \\
\text { дическими лицами }\end{array}$ & $\begin{array}{l}\text { Выставление счетов за оказанные } \\
\text { услуги (1 раз в месяц) }\end{array}$ & В течение последующих 45 дн \\
\hline
\end{tabular}

Таблица 2. Методы управления, применяемые для организации процесса оплаты расходных обязательств медицинской организацией

\begin{tabular}{|c|c|}
\hline Группа платежей - кассовых расходов & Метод управления \\
\hline $\begin{array}{l}\text { Выплата заработной платы, отчислений во внебюд- } \\
\text { жетные фонды, уплата налогов }\end{array}$ & $\begin{array}{l}\text { Планирование фонда оплаты труда помесячно, кон- } \\
\text { троль за формированием ФОТ, управление фондом } \\
\text { стимулирующих выплат, организация оплаты труда } \\
\text { по показателям эффективности, организация про- } \\
\text { цесса начисления заработной платы }\end{array}$ \\
\hline $\begin{array}{l}\text { Ежемесячные платежи за содержание (оплата комму- } \\
\text { нальных услуг, другие ежемесячные платежи услов- } \\
\text { но-постоянного размера) }\end{array}$ & $\begin{array}{l}\text { Организация процесса заключения договоров, } \\
\text { контроля за объемом услуг, учета счетов за услуги, } \\
\text { помесячное планирование платежей }\end{array}$ \\
\hline $\begin{array}{l}\text { Оплата услуг, проводимых периодически (техниче- } \\
\text { ское обслуживание оборудования, производственный } \\
\text { лабораторный контроль, обучение сотрудников и } \\
\text { т.д.) }\end{array}$ & $\begin{array}{l}\text { Составление годового графика, отслеживание цен на } \\
\text { услуги в течение года, контроль за объемом услуг }\end{array}$ \\
\hline $\begin{array}{l}\text { Плата за разовые услуги (ремонт оборудования, авто- } \\
\text { транспорта) }\end{array}$ & $\begin{array}{l}\text { Создание резерва на незапланированные меропри- } \\
\text { ятия }\end{array}$ \\
\hline $\begin{array}{l}\text { Плата за приобретенные материальные ценности, в } \\
\text { основном за медикаменты }\end{array}$ & $\begin{array}{l}\text { Планирование расходов в рамках ПФХД по источни- } \\
\text { кам финансирования, работа комиссий по состав- } \\
\text { лению заявок на приобретение, организация дого- } \\
\text { ворного процесса, составление заявок на поставки, } \\
\text { управление сроками оплаты, графиками платежей }\end{array}$ \\
\hline
\end{tabular}

является основополагающим для обеспечения платежеспособности организации и затрагивает множество финансовых отношений (с работниками, налоговыми органами, поставщиками товаров и услуг).

Необходимо отметить, что сведения о кассовых расходах, относящихся к определенному виду медицинской помощи, не в полной мере фиксируются в учете, что допускает возможность некорректного отнесения расходов к тому или иному виду медицинской помощи. В отчетной информации о расходной составляющей при оказании определенного вида медицинской помощи могут быть допущены искажения.

В настоящее время отсутствует отчетность, отражающая итоги деятельности медицинской организации по оказанию услуг, по выполнению плановых объемов доходов и расходов, финансовому результату и показателям эффективности финансовой деятельности, а также результативности оказания медицинской помощи. Учитывая социальную значимость сферы здравоохранения и необходимость обеспечения безубыточности медицинских организаций, такой документ необходимо разработать и предусмотреть в составе отчетности. 
Финансовый механизм медицинской организации, используемый в настоящее время, можно представить в виде схемы (рисунок 1).

Таким образом, финансовому механизму медицинской организации в настоящее время свойственны следующие черты.

1. Стадия стратегического планирования на уровне ЛПу характеризуется низким качеством. Медицинская организация не планирует самостоятельно свою деятельность, исходя из принципов эффективности оказания услуг, в частности, по причине отсутствия информаци- онной базы.

2. Оперативное управление финансово-хозяйственной деятельностью медицинской организации характеризуется слабым контролем за соответствием производимых расходов доходам от оказанных услуг, что обусловливает финансовые риски в течение года.

3. Отсутствует блок управления безубыточностью, благодаря которому должны быть решены две задачи: обеспечение платежеспособности организации (в текущем периоде и стратегическом плане) и предоставление ин-

БЛОК 1 - Стратегическое планирование на 3-летний плановый период

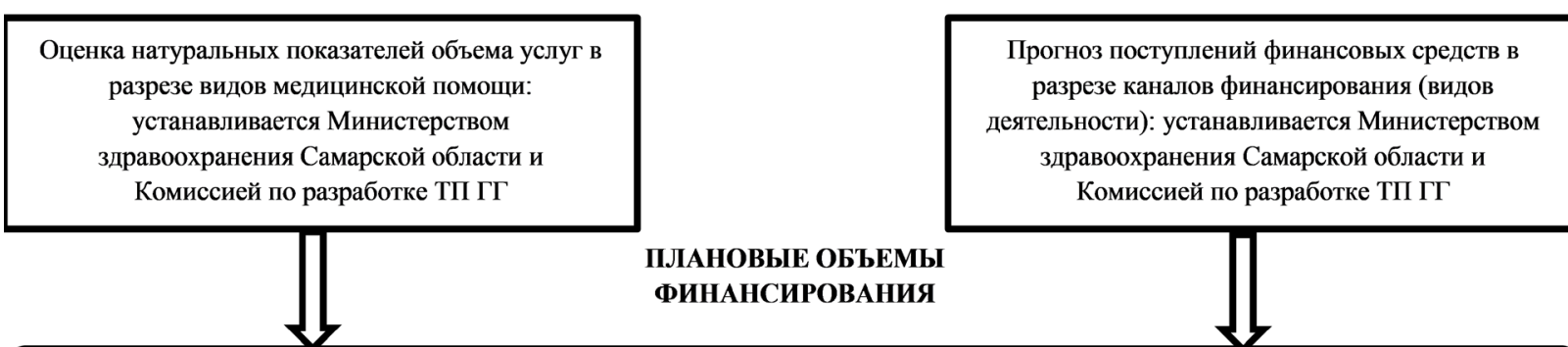

БЛОК 2 - Текущее планирование

Планы оказания медицинских услуг по видам помощи, подразделениям

ПФХД

ПЛАНОВЫЕ ЗНАЧЕНИЯ ПО

СТАТЬЯМ РАСХОДОВ
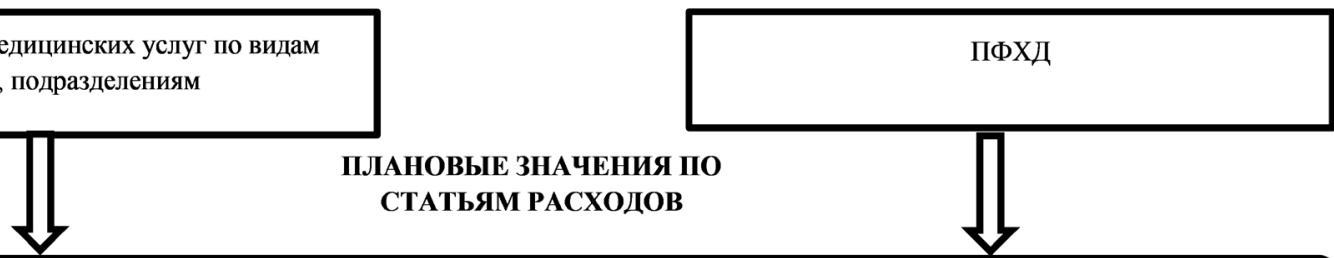

БЛОК 3 - Оперативное управление

Мониторинг выполнения планов оказания услуг по видам помощи, подразделениям

Исполнение ПФХД по доходам и расходам, внесение изменений в ПФХД
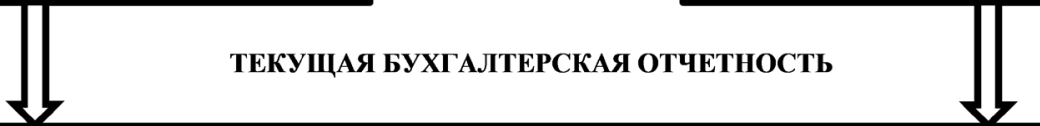

БЛОК 4 - Оценка эффективности и результативности оказания медицинской помощи

Сведения об оказании и ресурсном обеспечении медицинской помощи

Годовая бухгалтерская отчетность

Выполнение индикаторов государственной программы развития здравоохранения

Puc. 1. Состав финансового механизма медицинской организации 
формации для принятия управленческих решений по производственной деятельности. Расчет таких показателей, как рентабельность услуги, подразделения, вида помощи и медицинской организации в целом, позволит выявить ее проблемы, чтобы добиться эффективной работы.

4. Отсутствует система оценки эффек- безубыточности организации.

\section{Библиографический список}

1. О Порядке проведения мониторинга и контроля за выполнением государственного задания государственными бюджетными учреждениями Самарской области, подведомственными министерству здравоохранения Самарской области [Электронный ресурс]: приказ м-ва здравоохранения Самар. обл. от 10.02.2015 № 179.- - Режим доступа: http://minzdrav.samregion.ru/documents/prikazy/.

2. Объемы предоставления медицинской помощи и финансовых средств на обеспечение государственных гарантий оказания населению Самарской области бесплатной медицинской помощи за счет средств ОМС на 2016 год [Электронный ресурс]: протокол Комиссии по разработке ТП ОМС № 13-2016 от 20.12.2016.Режим доступа: http://samtfoms.ru/docs/.

3. Бородина Т.А. Механизм согласования экономических интересов в системе здравоохранения / Т.А. Бородина, Е.А. Колесниченко // Сб. науч. Тр. кафедры политической экономии и мирового глобального хозяйства. / отв. ред. М.А. Коломейцева. Тамбов. 2011. 97 с.

4. Валиева Е.Н. Модернизация финансового механизма обязательного медицинского страхования в РФ // Вестник Самарского государственного экономического университета. 2013. № 2. С. 17-22.

5. Кадыров Ф.Н. Платные услуги в здравоохранении / под ред. акад. РАМН В.И. Стародубова. Москва. 2013.220 c.

6. Курнакина Н.В. Финансовый механизм медицинских организаций в РФ // Вестник Самарского государственного экономического университета. 2014. № 11. С. 119-124.

7. Сюркова, С.М. Проблемы финансирования учреждений здравоохранения в период трансформации организационно-правовых и экономических условий их деятельности / С.М. Сюркова, Г.Г. Закирзянова // Вестник ТИСБИ. Томск, 2013. - № 2. С. 106-116. 



\section{ECONOMICS AND SOCIOLOGY}

№2 (38)

2018 


\section{CONTENTS}

\section{SOCIOLOGY}

\section{THEORY, METHODOLOGY AND HISTORY OF SOCIOLOGY}

Khodykin A.V. Theoretical understanding of vocational guidance of schoolchildren

in the context of sociological approach

\section{SOCIAL STRUCTURE, SOCIAL INSTITUTIONS AND PROCESS}

Khadjalova K.M., Abdulmanapov S.G. Protestant moods in the Republic of Dagestan (according to the data of the sociological survey) 60

\section{ECONOMY.ECONOMIC SCIENCE}

\section{ECONOMIC THEORY}

Lebedev K.N. Undeserved accusations of economic determinism, and why F. Engels did not disclose the method of K. Marx 60

Budovich Y.I. Did K. Marx have an economic view on economic activity? 61

\section{ECONOMICS AND MANAGEMENT OF NATIONAL ECONOMY}

Zeldner A.G. To the model of development of the Far Eastern territories: reality and prospects .. 62

Zakharchenko I.S. The essence and tools of anti-crisis management

\section{FINANCE, MONEY CIRCULATION AND CREDIT}

Livensky V.M. Functional importance of the stock market for the development of the economy of the Republic of Belarus .

Valieva E.N., Kurnakina N.V. Financial mechanism of medical organizations in Russia 63 


\title{
SOCIOLOGY
}

\section{THEORY, METHODOLOGY AND HISTORY OF SOCIOLOGY}

\section{THEORETICAL UNDERSTANDING OF VOCATIONAL GUIDANCE OF SCHOOLCHILDREN IN THE CONTEXT OF SOCIOLOGICAL APPROACH}

\author{
(c) 2018 Khodykin Alexander Vladimirovich \\ The Research Institute of Social Technologies \\ Samara National Research University named after Sergei Korolev \\ 34, Moskovskoye Shosse, Samara, 443086, Russia \\ E-mail: avhod@yandex.ru
}

The article highlights and describes in detail the following areas of theoretical understanding of vocational guidance of schoolchildren: career guidance as a socio-cultural process, as a social institution, as a social activity and as a system of social relations.

Key words: career guidance, schoolchildren, process, institute, activities, sociological approach, approaches to career guidance, research career guidance.

\section{References}

1. Dement 'ev I. V. Professional’naya orientaciya: analiz nauchny`x podxodov // Kiravanne u adukacyi. 2008. № 11 . S. 56-62. [Dement'ev V.I. Professional orientation: the analysis of scientific approaches // Cravenne have adocacy. 2008. No. 11. P. 56-62.]

2. Marks K. Razmy`shleniya yunoshi pri vy`bore professii // Marks K., E`ngel`s F. Sochineniya. 2-e izd. M.: Izd. polit. lit., 1975. T. 40. [Marx K. Reflections of a young man in choosing a profession // Marx K., Engels F. Compositions. 2-e Izd. M.: Izd. polit. lit., 1975. Vol. 40.]

3. Parsons T. Professii i social`naya struktura // Sociologiya. 2015. Vy`p. 4. S. 153-170. [Parsons T. Professions and social structure // Sociology. 2015. Vol. 4. P. 153-170.]

4. Ponomarev I. V. Diskussionny`e voprosy`kross-kul`turny`x issledovanij vliyaniya gramotnosti na kognitivnoe razvitie i koncepciya simprakticheskogo obshhestva // Kul`turno-istoricheskaya psixologiya, 2007.- № 4. S. 59-67. [Ponomarev I. V. Discussion issues of cross-cultural studies of the impact of literacy on cognitive development and the concept of a sympathetic society / / Cultural and historical psychology, 2007. - № 4. P. 59-67.]

5. Czvy`k V.A. Professionalizaciya kak social`ny `j process //Vestnik RUDN, seriya «Sociologiya», 2003. - № 4. S. 258269. [Tsvyk V.A. Professionalization as a social process. Vestnik RUDN, series «Sociology», 2003. - № 4. P. 258269.]

6. Social`naya stratifikaciya sovremennogo rossijskogo obshhestva. Pod red. Z.T. Golenkovoj.- M., 2003. [Social stratification of modern Russian society. Ed. by Z.T. Golenkova.-M., 2003.] 


\title{
SOCIAL STRUCTURE, SOCIAL INSTITUTIONS AND PROCESS
}

\section{PROTESTANT MOODS IN THE REPUBLIC OF DAGESTAN (ACCORDING TO THE DATA OF THE SOCIOLOGICAL SURVEY)}

\author{
(c) 2018 Khadjalova Khadizhat Magomedovna \\ Doctor of Economic Sciences, Associate Professor \\ Leading researcher of the Institute of social and economic research of the Dagestan scientific center of \\ the Russian Academy of Sciences. \\ Professor of the chair «Project and Program Management» \\ Dagestan State University of National Economy \\ 75, Yaragskogo Street, Makhachkala, 367030, Republic of Dagestan, Russia \\ E-mail: chaha@mail.ru
}

\section{(C) 2018 Abdulmanapov Salihbek Gabibullaevich}

Doctor of Economic Sciences, Professor

Director of the Research Institute of Management, economics, politics and sociology

Dagestan State University of National Economy

75, Yaragskogo Street, Makhachkala, 367030, Republic of Dagestan, Russia

E-mail:salih@mail.ru

The article is devoted to the identification of protest moods of the residents of the republic were revealed in 2017. Comparison with the analogous author's research of 2007 was made. The reasons for the growing tension in society, the factors of protest activity of the population, as well as the patterns determining their intensity and character of manifestation were revealed. The results of assessing social tension in the Republic of Dagestan and the level of protest activity testify to the concerns and discontent of people in general with the social and economic situation in the region.

Key words: protest activity, protest moods, protest potential, the Republic of Dagestan.

Received for publication on 30.06.2018

ECONOMY.ECONOMIC SCIENCE

ECONOMIC THEORY

\section{UNDESERVED ACCUSATIONS OF ECONOMIC DETERMINISM, AND WHY F. ENGELS DID NOT DISCLOSE THE METHOD OF K. MARX}

(c) 2018 Lebedev Konstantin Nikolaevich

Doctor of Economics, Professor of the Department of Economic theory

Financial University under the Government of the Russian Federation

49, Leningradsky Prospect, Moscow, 125993, Russia

E-mail: KNLebedev@fa.ru

At the turn of the XIX-XX centuries the theory of social development of Marx was unfairly subjected 
to accusations of economic determinism, or in the interpretation of the economy as the only factor in the development of society, the basis of which was the Marx's expression «being determines consciousness» or «mode of production determines the superstructure.» However, the method used by Marx in the creation of his theories of economic and social development, namely the method of dialectical materialism, or, more specifically, the law of interaction of content and form, does not mean that if the mode of production determines the superstructure, the superstructure does not have a reverse effect on the mode of production, and they both together do not determine the development of society. Thus, the accusations of the Marxist theory of social development in economic determinism are unfounded. But the analysis of dialectical materialism also leads to the understanding that its laws are recruited from the world of organisms, and therefore it is an inadequate method of economic research. It is no coincidence that the position derived on its basis on the historical victory of socialism over capitalism was wrong. F. Engels agreed with the accusations of the Marxist theory of social development in economic determinism, as he preferred not to refer to the method used, since organicism in the economy was subjected to crushing criticism by K. Menger, and the fact of its use by K. Marx questioned the correctness of the above-mentioned main conclusion of his theory.

Key words: economic determinism, dialectical materialism, law of interaction of content and form.

Received for publication on 12.06.2018

\title{
DID K. MARX HAVE AN ECONOMIC VIEW ON ECONOMIC ACTIVITY?
}

\author{
(c) 2018 Budovich Yuliya Ivanovna
}

Doctor of Economics, Professor of the Department of Economic theory Financial University under the Government of the Russian Federation 49, Leningradsky Prospect, Moscow, 125993, Russia

E-mail: JBudovich@fa.ru

Soviet scientists in the field of political economy avoided to give examples of relations of production. One of the reasons for this situation was their unwillingness to expose to criticism for poor knowledge of the Economics of the founder of their science K. Marx. According to the model of the capital turnover of K. Marx, it is clearly seen that in the enterprise he sees only real values, in particular, he does not see his liabilities, among which capital is owned by capitalists. For this reason, K. Marx applied the concept of «capital» to the assets of the enterprise, in connection with which the property of capitalists to capital became property of capitalists to the means of production, which in fact belong to the enterprise. Examples of relations of ownership of the means of production would reveal this error of K. Marx. But the main reason was not the desire to save K. Marx from criticism. The fact is that the above substitution of concepts was the basis of the main contradiction of capitalism - between the social nature of production and the private nature of appropriation, which was one of the main proofs of the inevitable death of capitalism. To give it up meant to destroy that evidence, which the CPSU couldn't do.

Key words: production relations, property relations, ownership of means of production, ownership of capital. 


\title{
ECONOMICS AND MANAGEMENT OF NATIONAL ECONOMY
}

\section{TO THE MODEL OF DEVELOPMENT OF THE FAR EASTERN TERRITORIES: REALITY AND PROSPECTS}

\author{
(C) 2018 Zeldner Alexei Grigorievich \\ Doctor of Economics, Professor, Chief researcher \\ Institute of Economics of the Russian Academy of Sciences \\ 32, Nakhimovski prospect, Moscow, 117218, Russia \\ E-mail: zeldner@inecon.ru
}

The priority development of the Far Eastern Federal District is connected not only with the natural potential of this region, but also with the neighborhood with the countries of the Asia-Pacific region, which have investment and technological and innovative potential. The model of Far East development approved by the Government assumes attraction of direct investments, including foreign ones. A variant of solving this problem in the article is proposed by attracting high-tech foreign technologies on concession basis and methods of insurance of concessionaires risks.

Key words: territories of advanced development, development model, technologies, innovations, economic levers, concessions.

\section{THE ESSENCE AND TOOLS OF ANTI-CRISIS MANAGEMENT}

\author{
(c) 2018 Zakharchenko Igor Sergeevich \\ Graduate student \\ Leningrad State University named after A.S. Pushkin \\ 10, Petersburg Highway, St. Petersburg, Pushkin, 196605, Russia \\ E-mail: 193miller@gmail.com
}

The article examines the existing approaches to determine the essence of anti-crisis management of the enterprise; its interpretation as a set of management decisions and actions aimed at forecasting and identifying signals of possible threats, diagnosing the crisis state of the enterprise, developing and implementing methods for preventing and suppressing negative consequences, is offered. The tools of anti-crisis management of operational, tactical and strategic levels are characterized.

Key words: enterprise, crisis management, the process of crisis management, tools of anti-crisis management. 
FINANCE, MONEY CIRCULATION AND CREDIT

\title{
FUNCTIONAL IMPORTANCE OF THE STOCK MARKET FOR THE DEVELOPMENT OF THE ECONOMY OF THE REPUBLIC OF BELARUS
}

\author{
(C) 2018 Livensky Valentin Mikhailovich \\ Candidate of Geographical Sciences, Associate Professor of the Department of Finance \\ Polessky State University \\ 23, The Dnieper Flotilla Street, Pinsk, 225710, Republic of Belarus \\ E-mail: livey@tut.by
}

The article contains qualitative and quantitative analysis of the activity of the stock market of the Republic of Belarus; The study identified the problems of its functioning and attempted to find ways to solve them.

Key words: national economy, stock market, stock market, bond market.

Received for publication on 21.04.2018

\section{FINANCIAL MECHANISM OF MEDICAL ORGANIZATIONS IN RUSSIA}

\author{
(C) 2018 Valieva Elizaveta Nikolaevna \\ Doctor of Economics, Professor \\ Samara State University of Economics \\ 141, Soviet Army Street, Samara, 443090, Russia \\ E-mail:rad8063@yandex.ru \\ (C) 2018 Kurnakina Natalia Vladimirovna \\ $\mathrm{PhD}$ in Economics, Deputy Chief Physician for Economic Affairs \\ The Samara Dental Clinic No. 2 \\ 121, Freedom Street, Samara, 443009, Russia \\ E-mail: nv125@rambler.ru
}

The article is devoted to the issues of financial management in medical organizations. The composition of their financial mechanism is presented. The characteristic of its blocks and tools is given. The proposals aimed at the development of financial management methods in health care are formulated.

Key words: medical organizations, financial management in medical. 